\title{
HABITAR NO TEMPO DA CIDADE: UM ESTUDO SOBRE MEMÓRIA E SOCIABILIDADE NA REGIÃO DO PORTO DE PELOTAS/RS 1 .
}

\author{
Ícaro Vasques Inchauspe ${ }^{2}$ \\ Francisco Luiz Pereira da Silva Neto ${ }^{3}$
}

\section{Introdução}

Habitar no tempo da cidade? Qual a relevância deste tema para a antropologia, e que interpretações em relação a alteridade podemos extrair desta pergunta, que, aparentemente aparece tão simplória e em segundo grau desinteressada em virtude da força que a ideia tempo único opera em tempos de individualismo moderno?

Comecemos respondendo pela segunda. De fato, é uma pergunta ampla e relativa, que pode nos levar a diversos caminhos de observação e interpretação. Mas um ponto chave em comum que podemos constatar dessa inflexão em relação a disciplina antropológica é que ela nos permite mostrar que estes caminhos podem ser comparados e decifrados em uma perspectiva temporal através de narrativas que evidenciam a sua forma de habitar a cidade. Para produzirmos um deslocamento no tempo normativo e linear da cidade, aquele da cidade como empreendimento capitalista, é importante que a perspectiva pela qual percebemos a mesma seja a da experiência dos seus habitantes, dos sentidos que os eles produzem ao narrar a cidade e abrir sua compreensão a distintas temporalidades.

Ao tratar da carga de significados colocadas na produção de paisagens urbanas Rocha \& Eckert nos alertam:

\footnotetext{
“A construção da paisagem na trajetória humana não se reduz a deixar reger-se por modelos culturais ou a priori externos à consciência humana, mas de intenções afetivas, de motivações singulares que acomodam as sensibilidades potencializadas por um universo de signos e de imagens que imprimem ritmo aos deslocamentos em nossos percursos, em nossa trajetória, dando, assim, sentido a um tempo pensado e vivido, um tempo humano" (2013: 186).
}

\footnotetext{
${ }^{1} \mathrm{O}$ trabalho é fruto da pesquisa de dissertação de mestrado intitulada "Nos trilhos do tempo e no fluxo da cidade: Um estudo antropológico sobre memória e sociabilidades na região do Porto de Pelotas/RS" realizada entre 2017 e 2019.

2 Universidade Federal do ABC, São Paulo, Brasil. E-mail: icarovasques@gmail.com. ORCID: https://orcid.org/0000-0002-0105-9990

3 Universidade Federal de Pelotas, Rio Grande do Sul, Brasil. E-mail: francisco.fpneto@gmail.com@gmail.com. ORCID: https://orcid.org/0000-0001-6339-7605 
Portanto, o que estamos propondo neste texto é compreender o que pode significar habitar no tempo da cidade, e de que forma podem ser produzidos estes significados na realidade temporal das cidades brasileiras tendo com perspectiva a experiência de seus habitantes. Com o enfoque nos estudos das cidades de uma antropologia urbana, situamos através do relato etnográfico rastros, trilhas que norteiam o campo da memória e das sociabilidades onde, em seu jogo, são produzidas e trabalhadas possíveis contribuições tanto para compreender o que pode vir a ser habitar no tempo da cidade, e como a cidade é constituída no tempo de quem as habita.

Dando início a resposta da primeira pergunta elencada no começo desta introdução, tratamos neste trabalho então de expor uma temporalidade diacrônica junto com parceiros de pesquisa, em virtude de evidenciar como o bairro do Porto de Pelotas reverbera em primeiro lugar o campo antropológico de atuação: o que pode ser entendido como habitar na cidade; e em segundo lugar, uma análise da temporalidade das cidades brasileiras espelhadas em tempos diacrônicos e que consequências elas nos trazem para compreende-las a partir de disputas de narrativas e conflitos pelos sentidos de pertencimento como habitantes da cidade.

Um outro aspecto importante de nossa reflexão diz respeito a relação da materialidade arquitetônica do Porto - a qual expressa o investimento do poder local na constituição de um espaço urbano-industrial em meados do século XX - no jogo de construção de memórias que são articulados na experiência de viver a cidade. Não há como negar a presença ativa de uma certa "monumentalidade" dos prédios industriais que configuram o bairro do Porto. O passar do tempo transforma o monumento em ruína e abre a possibilidade de (re)arranjos urbanos através do tempo que produz uma nova configuração material que podemos denominar monumento/ruína.

Neste sentido, nosso contexto de análise etnográfico e ponto de partida efetivouse através do bairro do Porto na cidade Pelotas, localizado no extremo sul do Rio Grande do Sul. Um bairro que, se observado em sua duração, apresentou diversas continuidades e rupturas, as quais desenvolveram representações simbólicas fruto de suas transformações socioculturais e históricas que deram forma a uma pluralidade de contextos e ritmos diferentes de vida e de ação cotidiana produzidos por seus habitantes.

Deste modo, na busca pela interpretação de uma possível temporalidade do bairro, o trabalho ancorou-se na realização de diferentes observações etnográficas. A primeira, por meio dos estudos da memória e da rememoração, quando estabelecemos como prática e método a etnografia da duração (Rocha \& Eckert, 2011) com o intuito de compreender 
as temporalidades narradas e performatizadas pelo interlocutor e citadino, além de exmorador do bairro, Jonas Santos, que por meio de sua trajetória biográfica na condição de herdeiro urbano, reivindica uma identidade coletiva, demarcando uma determinada temporalidade negra, fabril, operária e marginalizada.

Até a segunda e possível caracterização do bairro, em seu tempo atual, permitiu a inserção etnográfica em diferentes eventos, além de ações do cotidiano por meio das sociabilidades observadas e praticadas, que estabelecem um cenário juvenil-universitário, a partir da instalação da Universidade Federal de Pelotas espalhadas ao longo da região do bairro. Portanto, a partir desta pesquisa foi possível compreender ao menos dois tipos de temporalidades do bairro.

Por meio de narrativas que evidenciam perspectivas históricas de viver na cidade, estabelecendo uma interpretação para escalas e ritmos urbanos distintos do e no bairro, determinando as práticas destes cotidianos, estabelecendo territórios e demarcando identidades plurais na trama urbana, inseridas em uma constante negociação de sentidos, com base na reordenação da duração de um tempo específico no bairro ${ }^{4}$.

\section{Habitar no tempo da cidade: contribuições socioantropológicos na formação da interpretação sobre o urbano}

Gostaríamos inicialmente neste trabalho, do qual tem a intenção de propor uma reflexão sobre o tempo das cidades, na forma de prosseguir contribuindo com a temática dos estudos antropológicos, do qual tem seu 'inicio' a partir de de $1930^{5}$, no surgimento dos primeiros estudos sociais e culturais sobre a configuração urbana do Brasil

\footnotetext{
${ }^{4}$ Para tratar de identidade no contexto deste trabalho, nos referenciamos no conceito de identidade narrativa, de Ricouer, resgatado com segue por Maria Luísa Portocarrero Silva: "Tudo o que se desenrola no tempo pode, com efeito, ser contado e tornar-se motivo de uma narrativa, e reciprocamente tudo o que é contado situa-se necessariamente no tempo, leva tempo e desenrola-se de modo temporal. É pois no caráter temporal do ato de narrar que o filósofo se baseia para meditar a temporalidade do si próprio : já que não somos um ser atemporal, imediato e redutível à categoria do Cogito imediato; já que apenas somos por meio das nossas ações e testemunhos e existimos primeiro perdidos e disseminados, em múltiplas tarefas e atividades, só a história da nossa vida nos mostra o que realmente somos. Só uma vida examinada é inteiramente vivida, daí a narrativa fazer parte integrante da construção da minha identidade. Esta não se resume apenas ao que recebi em termos de herança biológica, a identidade idem, marcada pelo caráter e pelo que eu herdo com o meu corpo, um genótipo ou o conjunto de traços imutáveis que em qualquer pessoa se mantêm os mesmos ao longo do tempo" (Silva, 2013:33).

${ }^{5}$ Podemos tomar este período como um dos precursores sobre o fenômeno urbano e o cotidiano da cidade com Dina Dreyfus no Departamento da Cultura de São de Paulo sob convite de Mário de Andrade, realizando pesquisas folclóricas, etnográficas e de reconhecimento de tradições culturais paulistas. Como também o próprio marido de Dreyfus, Lévi-Strauss, no qual relata em Tristes Trópicos a sua passagem melancólica no Centro-Oeste do país, sob as condições e cenário urbano do qual transitava em suas pesquisas de campo. Em paralelo com pesquisas antropológicas urbanas iniciais, já havia a publicação de Gilberto Freyre em 1933 com Casa Grande e Senzala revelando passagens temporais das cidades brasileiras e seus sistemas escravocratas.
} 
produzidas ao longo do tempo, e que, ao mesmo tempo nos servem como base intelectual teórica-metodológica na produção deste trabalho.

A ênfase de nossa abordagem reflete a importância da etnografia e seus recursos metodológicos e analíticos para conhecer a realidade urbana. Propõe também a aproximação a outras disciplinas, conforme a própria ideia do antropólogo Gilberto Velho, que nos atenta para observar a cidade a partir de aspectos da história e da sociologia, complexificando o entendimento das dinâmicas e interações sociais das e nas cidades.

Segundo Velho (1994), a ideia de sociedades complexas busca traçar reflexões acerca de um sistema particular de vida moderno - o sistema das sociedades complexas através da realidade brasileira e observado diante da metrópole. Por meio da interdisciplinaridade das Ciências Sociais percebe-se a heterogeneidade social, com base nas diferentes classes sociais que habitam um grande arranjo urbano que se forma, estabelecido a partir da coexistência de diferentes estilos de vida e visões de mundo que são postos em negociação para criação de suas realidades.

Dessa forma, a heterogeneidade é resultante da divisão social de trabalho e da estratificação social, particularmente acentuada no meio urbano. Nas sociedades complexas, afirmava Velho, coexistem diversos grupos sociais, com estilos de vida, visões de mundo e códigos distintos - regras de comportamento e formas de linguagem específicas que, muitas vezes, apresentam fronteiras relativamente bem demarcadas.

Na demarcação dessa complexidade proposta entre as múltiplas organizações da vida social em coletivo, por meio de uma unidade, havia um outro componente importante como bem observado por Gilberto Velho, que destacava a formação moderna dos indivíduos a partir também de uma heterogeneidade cultural e, consequentemente, da fragmentação difundida em subsistemas da vida social urbana, além de elementos determinantes como a estrutura social e seus sistemas de hierarquias. Ao conceituar as sociedades complexas, Velho propõe:

[...] a sociedade complexa que tenho em mente, a noção de uma sociedade na qual a divisão social do trabalho e a distribuição de riquezas delineiam categorias sociais distinguíveis com continuidade histórica, sejam classes sociais, estratos, castas. Por outro lado, a noção de complexidade traz também a ideia de uma heterogeneidade cultural que deve ser entendida como a coexistência, harmoniosa ou não, de uma pluralidade de tradições cujas bases podem ser ocupacionais, étnicas, religiosas etc. Obviamente existe uma relação entre estas duas dimensões - a divisão social do trabalho e a heterogeneidade cultural. (2013: 88). 
Concordamos com a percepção de Velho de que a vida nas cidades modernas é um fato social produzido em larga escala diante das condições estruturantes de organização das sociedades complexas, contudo, não é um dado social e cultural pronto. Esta última observação, atrelada a questão da temporalidade, pode ser entendida aqui como ponto inicial para nossa análise sobre a realidade sociocultural na conformação das cidades, consequentemente, consideramos a cidade contemporânea como um sistema criado por meio de situações heterogêneas.

Um dos primeiros aspectos a partir do qual podemos demarcar o sintoma deste arranjo inicial é, principalmente, pela Revolução Industrial propriamente dita, que criou um tipo de sociedade cuja complexidade está fundamentalmente ligada a uma acentuada divisão social do trabalho, ao espantoso aumento da produção e do consumo, à articulação de um mercado mundial e a um rápido e violento processo de crescimento urbano (Hobsbawm, 1975).

Inserido no contexto da pesquisa, cabe ressaltar que a cidade de Pelotas, bem como o bairro do Porto, no século XX, foi e é considerado um importante espaço de modernização, trazendo inúmeros grupos étnicos, famílias, indivíduos para povoar e habitar o bairro. De modo geral, podemos compreender que as sociedades complexas industriais modernas abrangem uma população numerosa e diversificada devido ao desenvolvimento das forças produtivas. A partir da diacronia que este tipo de sociedade produziu, aliada ao aperfeiçoamento da técnica e da ciência, a região pode ser compreendida em consonância com suas múltiplas metamorfoses urbanas, como um bairro fabril, agroindustrial, portuário e universitário, mapeado a partir de seus agentes empíricos.

Ao estudarmos a temporalidade do bairro sob aspectos que denotam e conformam as sociabilidades produzidas diante do tempo, também podemos identificar problemas, como o da unidade e descontinuidade destas atividades ao longo do tempo. Sendo assim, a partir de determinadas características que fazem parte das sociedades complexas, tratamos de efetivar esta transposição conceitual de análise por meio da observação dos vínculos e das sociabilidades entre grupos e indivíduos no bairro, nas suas distintas e diversas temporalidades que foram apresentadas na pesquisa, situadas em um contexto de escala de cidade média, como se configura a cidade de Pelotas.

Este exercício de modo comparado pode ser exemplificado a partir de antropólogos que estudam as metrópoles e suas formas de sociabilidade no tempo e, ao mesmo tempo, evidenciam dilemas contemporâneos de seus contextos, como a grande 
expansão populacional, sistemas de transporte, mobilidade e suas mazelas, como a violência. Dentre inúmeros trabalhos, cito alguns com os quais busco promover um diálogo dentro desta pesquisa, como José Magnani em São Paulo, Ana Carvalho da Rocha e Cornélia Eckert, em Porto Alegre, além de Gilberto Velho, um dos fundantes da temática, no Rio de Janeiro. A grande metrópole, é, portanto, o lócus por excelência das realizações e traços mais característicos desse novo tipo de sociedade (Velho, 1997: 12).

Portanto, se as metrópoles podem apresentar estas variáveis de análises destacadas, será que podemos abordar as mesmas variáveis em cidades de menor escala? De que forma podemos observá-las? Como diferenciá-las em categorias, além da demográfica, resguardando suas características e especificidades?

Um possível caminho para compreender estes agenciamentos urbanos identificados no bairro do Porto, como observado na pesquisa, foi possível a partir da abordagem de Velho, onde possibilitou transpor o conceito para outra escala e perspectiva de cidade: da metrópole para uma cidade média, contendo traços interioranos e metropolitanos. Muito em virtude, da constatação e inserção de novos (no sentido literal da palavra) moradores, e principalmente dada sob a qualidade destas trocas, seja na criação de novas práticas urbanas no bairro e sua complexidade das inter-relações (em suas diferenças e diversidades) na forma de enxergar ou habitar o bairro, propondo-nos diferentes perspectivas de observação.

No contexto de pesquisa - Pelotas -, pôde ser apurada a pluralidade de diversos grupos e indivíduos, advindos do próprio estado do Rio Grande do Sul, do Brasil e da América Latina, até mesmo de outros continentes. Diante da modificação de suas práticas estabelecidas na cidade de Pelotas, de modo geral e em função de sua 'vocação' para o espaço educacional no âmbito universitário, o que acabou produzindo uma inserção massiva de novos moradores, transeuntes e frequentadores acarretando dinâmicas, atividades de criação, equipamentos e serviços apurados de caráter juvenil no bairro do Porto. A partir da nossa proposta de discussão deste trabalho, tratamos de refletir sobre a pluralidade e diferença de interação e formas de vida no âmbito urbano e local, como também na identificação destas atividades, e sua duração ao longo da transformação dos citadinos.

Procuramos estabelecer dimensões temporais pelas quais o bairro passou e vem passando, sem produzir uma totalidade de todos os seus fatos e acontecimentos, mas sim, caracterizando momentos e passagens dos territórios diversos que conformam o bairro por meio de uma interpretação antropológica sobre práticas urbanas. A apuração das 
transformações locais com o enfoque na duração temporal das narrativas apresentadas pretende fortalecê-las como ferramenta de visibilidade sobre determinadas práticas dos seus citadinos no e do bairro, basilares para a constituição dos sentidos que habitam o território do vivido.

\section{Pelotas e o bairro do Porto como reflexo do tempo social Brasileiro}

Se no primeiro capítulo abordamos conceitualmente aspectos históricos, sociológicos e antropológicos que fundam matrizes primordiais de análise no campo social e cultural para a observação etnográfica na esfera das cidades urbanas-industriais, neste que prossegue, abordaremos de forma mais exemplificada como o tempo social do Brasil (Freyre, 1959) pode ser interpretada a partir de suas distintas realidades na cidade de Pelotas.

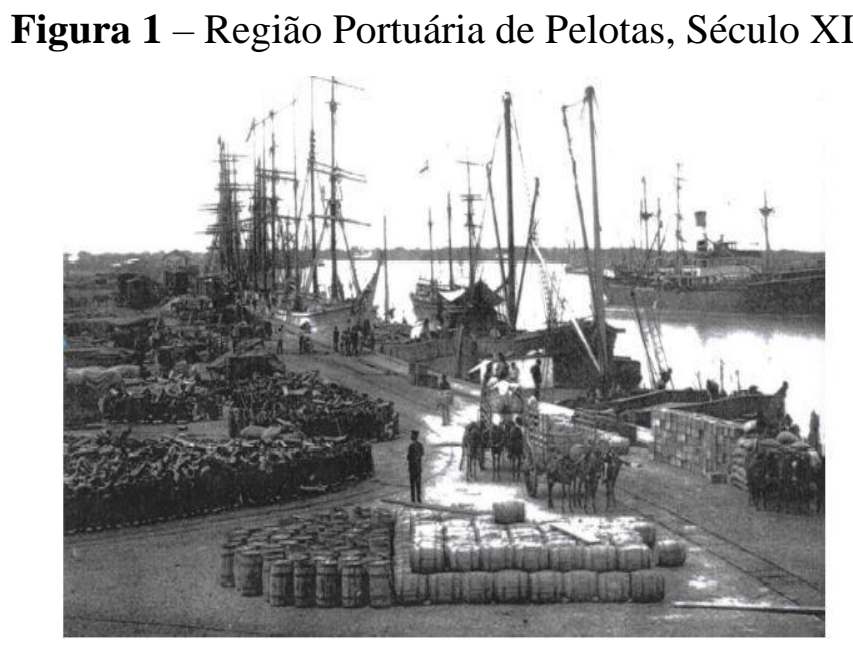

Fonte: Acervo dos autores.

A proposta deste capítulo é seguirmos navegando pelo bairro, a fim de descobrir caminhos inesperados, diante do ato de conhecer o cotidiano da cidade em suas variáveis. O ponto de partida será apresentar o bairro por meio da inserção de elementos materiais e visuais, que nos dão pistas para caracterizar as formas de vida e a configuração da cidade em sociedades complexas.

Cabe destacar o marco temporal histórico que dá forma à região portuária. Segundo Essinger (2009) e Gutierrez (2004), respectivamente em suas pesquisas sobre a memória do bairro e a cidade de Pelotas, apontam que o lugar teve seu desenvolvimento 
no ano de 1832 , com o loteamento existente por famílias charqueadistas ${ }^{6}$. Com o forte apoio da Câmara Vereadores, declarou a proibição de construções em uma faixa de 22 metros, às margens do São Gonçalo, mandando ainda que se construísse um trapiche onde pudessem atracar os barcos. Essinger (2009) nos informa que dois anos mais tarde as margens do canal foram declaradas como logradouro público ${ }^{7}$. Desta forma, com o aumento crescente da rota portuária pelotense, o local foi reconhecido como o ponto principal de embarque e desembarque de mercadorias.

Figura 2 - Região Portuária de Pelotas como cartão postal entregue aos Reis de Portugal

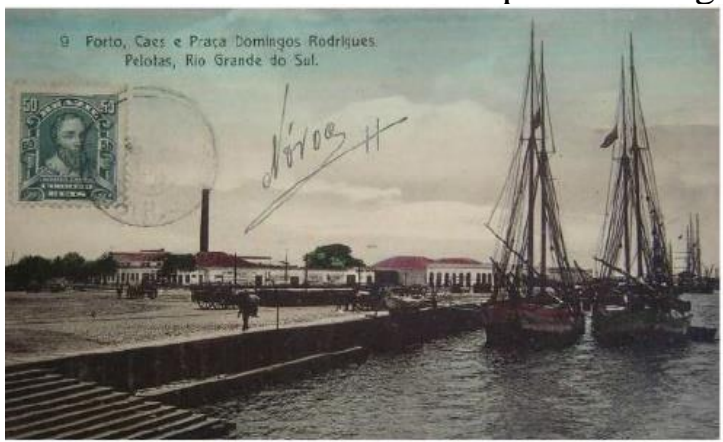

Fonte: Acervo dos autores.

Com medidas de aprimoramentos pela Intendência Municipal, houve um entendimento da necessidade de povoamento do bairro, em virtude do crescimento da cidade. Portanto, em 1912, se constrói a Paróquia Santuário do Sagrado Coração de Jesus na rua Aquidaban, atual Coronel Alberto Rosa, esquina com Gomes Carneiro, existente até hoje. A partir desse planejamento urbano, é que, em 1920, há uma acentuada mudança do bairro em razão da volumosa inserção de indústrias, alavancada pela localização estratégica do Porto.

\footnotetext{
${ }^{6} \mathrm{O}$ contexto da formação e desenvolvimento da cidade advém das atividades relacionadas a cadeia da produção de alimentos._Parte da produção intensiva da carne para a produção do charque e passa depois para a monocultura do arroz, substituindo a bovinocultura e a ovinocultura para a produção de lã. Em conjunto há uma policultura colonial de produtos como o milho, vinho, a banha, erva-mate, o trigo, feijão, cana-de-açúcar e a cebola. Para mais informações sobre estes temas, ver Da Rocha e Becker (2000), Martinez (2000), Alonso (2003).

${ }^{7}$ Conforme aponta Ester Gutierrez (2004: 141-142), logradouro público “constituía espaço destinado ao bem comum e de reserva para expansão urbana. Serviria, também para o pasto de animais, coleta de madeiras e lenhas, para algum plantio e para novas divisões de terras, abertura de estradas, ruas e praças. A câmara deveria administrar, preservar e zelar para que o patrimônio público não sofresse invasões por parte de quem fosse".
} 
Figura 3 - Inicio das atividades da Cervejaria Brahma.

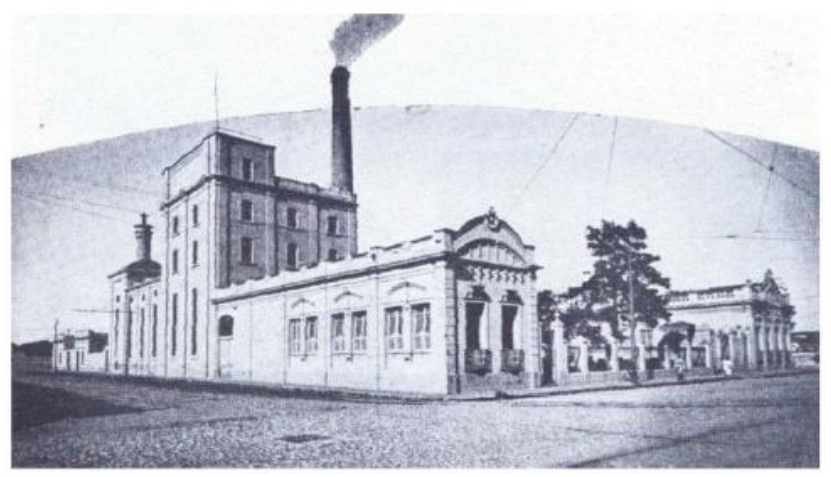

Fonte: Acervo dos autores.

Constituindo um múltiplo cenário portuário da época, que perdura até os dias atuais, demarcando mobiliários urbanos, com extensos casarões e calçadas largas para passeios, assim como um amplo complexo de edificações fabris, além do extenso porto modificado ao longo dos anos. Após este primeiro período do século XX habitado em função da industrialização local, o bairro foi se constituindo enquanto polo agroindustrial, ao passo que também é marcado pelas construções dos casarões de uma parte da elite burguesa em Pelotas que se encontrava em ascensão na época.

O declínio fabril-industrial perdura até o final dos anos 1980, em razão de estratégias políticas nacionais do setor industriário, tendo como a principal medida, a desoneração do investimento público de subsídios para as indústrias brasileiras, da isenção de tributos e incentivos fiscais. Em contramedida, já se desenvolvia a efetivação de uma transição do transporte das mercadorias, em virtude da eficiência, do tempo e do custo benefício. Da água (por meio dos navios cargueiros) para a terra (caminhões), o plano de desenvolvimento rodoviário por meio de obras de infraestrutura faraônicas ${ }^{8}$ (BEAL, 2010) mudou radicalmente o modelo de transporte de mercadorias no Brasil. Esta política provocou o deslocamento das empresas agroindustriais para outros centros urbanos, ocasionando um movimento de abandono de muitas atividades agroindustriais no Porto e seu desuso como principal ponto de transporte de mercadorias da cidade. Um

\footnotetext{
${ }^{8}$ Termo referenciado ao período dito popular "milagre econômico promovido pelo governo militar, devido as amplas construções realizadas em torno do Brasil, mais especificamente na realização da Transamazônica, Hidrelétrica de Itaipu, Ferrovia de Aço, Embratel, entre outros. Neste período, foi aperfeiçoado o modelo desenvolvimentista iniciado por Juscelino Kubitschek.
} 
dos efeitos desse processo foi a grande degradação visual do bairro exposta com o passar dos anos 9

Figura 4 - Entorno da Empresa pontuaria-marítima Sagres, 2017.

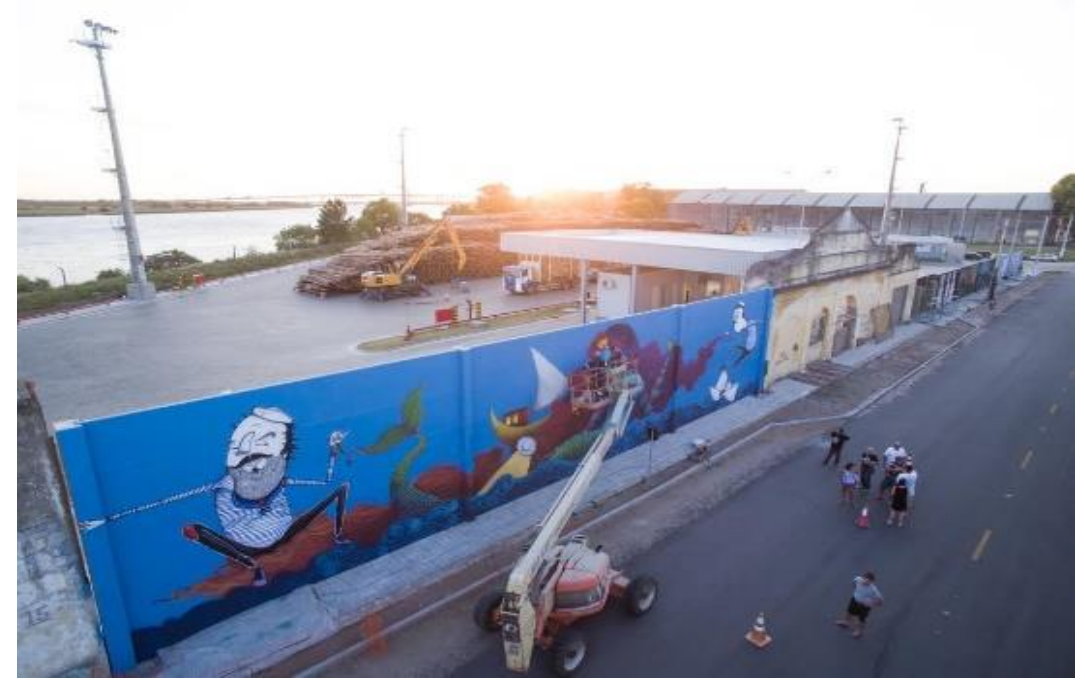

Fonte: Acervo dos autores.

Com algumas políticas de incentivo tímidas por parte do município, a região portuária ainda atrai algumas empresas do setor industrial, operando atualmente em áreas do setor eletroeletrônico como é caso da empresa Freedom, que atua na produção de cadeiras de rodas, veículos elétricos, além do escoamento de insumos como o eucalipto, por meio da empresa Sagres. Esta empresa atua em um amplo domínio de prestação de serviços como a logística internacional de mercadorias, armazenamento de cargas e agenciamentos marítimos. Uma empresa estratégica para o impulso tanto para o setor econômico-portuário quanto para outros setores, como o artístico-cultural no patrocínio de atividades que veremos mais adiante. Vale frisar que também foram gerados muitos conflitos ambientais ${ }^{10}$ e sociais, entre comunidade e poder público.

\footnotetext{
${ }^{9}$ Além do bairro do Porto, a decadência da indústria frutífera, compoteira e conserveira da cidade, como empresas da Vega e Oderich diminuíram muito a escala da produção, conforme pode ser visto um abandono dos galpões localizados à beira da BR 116.

${ }^{10}$ Para mais informações sobre o tema, ver o trabalho de Karpinski e Adomilli (2009).
} 
Figura 5 - Fábrica Moinho Pelotense, 2017.

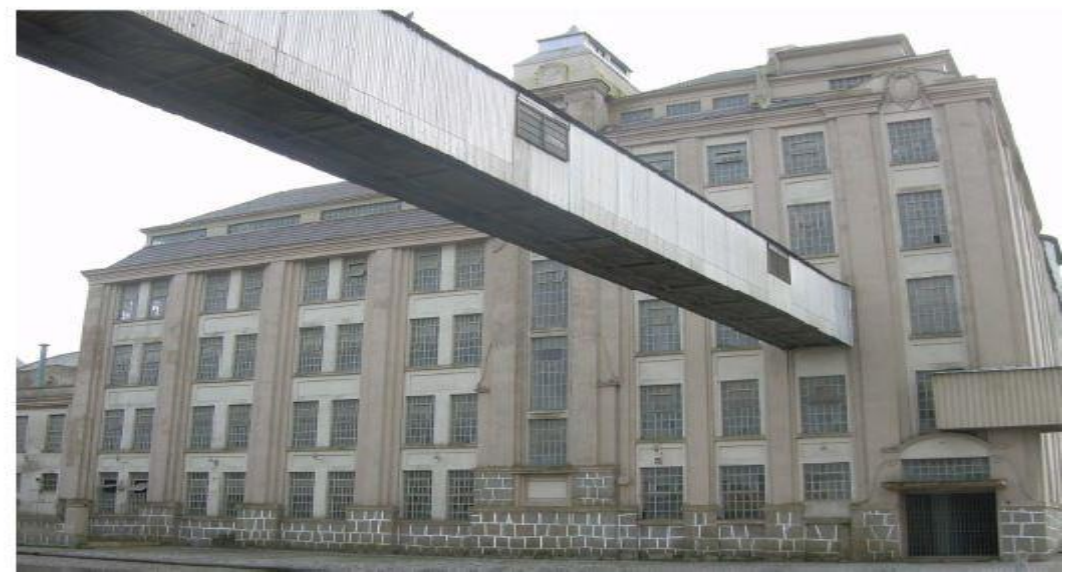

Fonte: Acervo dos autores.

É possível observar no Porto como uma mudança temporal do bairro coloca em perspectiva de análise a evolução das tecnologias, mudanças nas atividades cotidianas e os saberes de um determinado tempo.

Por exemplo, os conjuntos fabris-industriais serviam como trabalho para milhares de pessoas, famílias e gerações de trabalhadores atuantes no ramo alimentício como os matadouros e frigoríficos, as cervejarias, as panificadoras, as doceiras em compotas de pêssego, além das entre safras de arroz, milhos, grãos em geral.

Já no setor de rouparia, as indústrias laneiras e têxtis na produção de tecidos. E ainda no setor portuário, com os pescadores, enlatados pesqueiros e na força braçal dos estivadores ${ }^{11}$ a bordo dos navios cargueiros na organização e retirada das cargas.

\footnotetext{
${ }^{11}$ O estivador é o técnico responsável pela colocação, retirada e/ou arrumação de cargas nos porões ou sobre o convés de embarcações principais e auxiliares, autopropulsadas ou não. Utiliza-se, para tanto, vários recursos técnicos disponíveis sendo habilitado para operar todos os equipamentos de movimentação de carga presentes na embarcação (guinchos, tratores, empilhadeiras, sistemas semiautomatizados e automatizados para movimentação de cargas). O estivador é imprescindível para execução do transporte marítimo, ficando encarregado da movimentação e sinalização para movimentação de cargas e equipamentos a bordo. Também executa ações de contingência em caso de acidentes, seja retirando a carga ou a pessoa ferida como também efetuar combate a incêndios e outras ações. Até a primeira metade do século XX, cabia aos estivadores a tarefa de embarcar a carga nos navios transportando parcelas dela nas costas, frequentemente embaladas em sacos de 60 quilos.
} 
Figura 6 - Companhia de Fios e Tecidos, 2017.

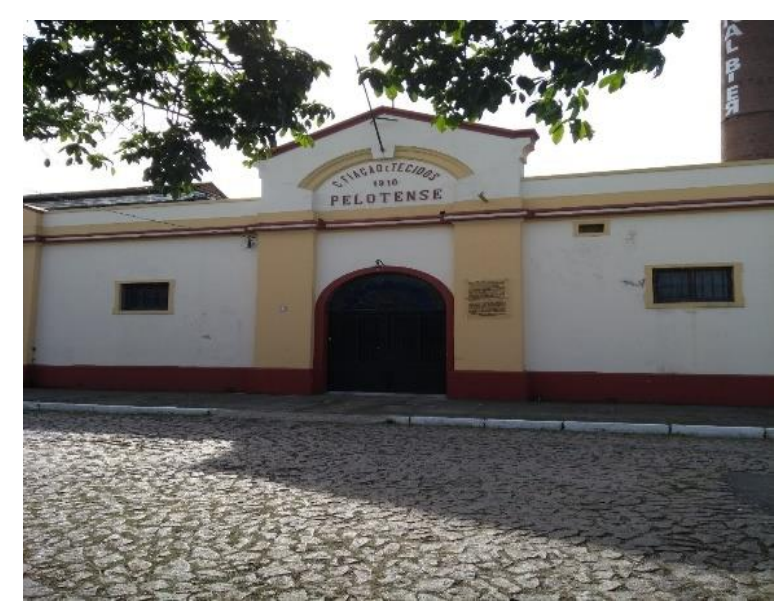

Fonte: Acervo dos autores

Figura 7 - Sindicato dos Estivadores, 2017

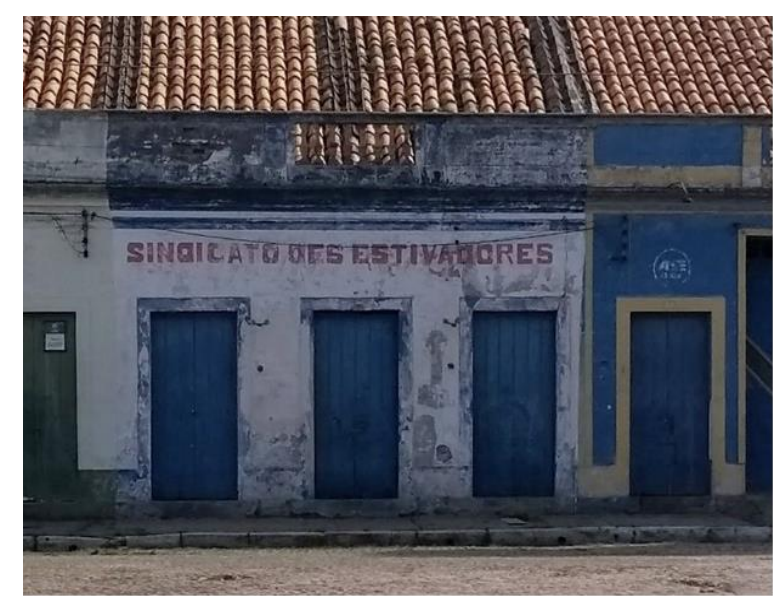

Fonte: Acervo dos autores

A fim de ambientar o bairro do Porto realizamos incursões de caráter etnográfico caminhadas e observações ao longo do trabalho de campo. Nelas produzimos registros fotográficos que configuram o cenário fabril-industrial e portuário deixando marcas, materialidades e resquícios ou rastros (Ricouer,1983) de antigos itinerários urbanos no Porto, que nos mostram uma outra cidade marcada pelo tempo.

Essencial para essa do trabalho quando busca-se compreender como a memória e o tempo podem ser retomadas na formação das cidades brasileiras em uma interpretação antropológica, à medida em que são vinculadas a reconstrução de histórias, trajetórias de vida e itinerários urbanos. Mais especificamente sob o contexto da pesquisa que busca traçar diferentes temporalidades, usos, saberes e práticas no cotidiano na cidade de Pelotas, principalmente no bairro do Porto. Aqui é importante ressaltar novamente que 
nossa perspectiva de trazer a compreensão da cidade através das temporalidades experienciadas pelos habitantes da cidade precisa estar conectada com as transformações no nível econômico, uma vez que a economia é uma força estrutural, especialmente em cidades modernas.

Destacamos que a cidade, no geral, e o bairro especificamente foram e são cenários de diversas mudanças socioculturais desde o seu período colonial-rural com as charqueadas e seu regime de escravidão no Brasil Meridional. Passando pelo processo de inserção das sociedades urbanos-industriais, que, em medida, trouxeram um amplo complexo fabril e agroindustrial para o bairro, até a sua decadência e desuso devido ao esvaziamento das empresas em virtude do deslocamento para outras cidades do estado gaúcho em razão das questões de logística, tributações, entre outros.

Figura 8 - Antiga Cervejaria Brahma, 2017.

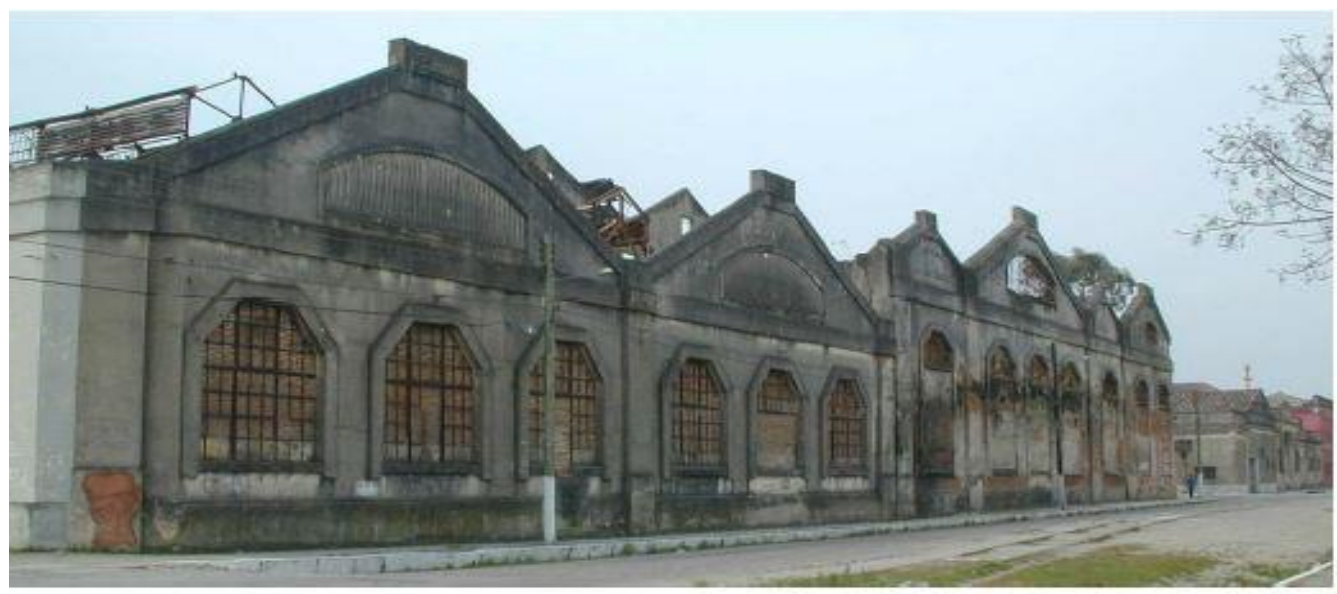

Fonte: Acervo dos autores.

A partir deste hiato que se situou no bairro do ponto de vista dos investimentos econômicos, foram sendo estabelecidas políticas urbanas por meio dos Planos Diretores para a preservação do patrimônio cultural da cidade. Tendo seu início em 1967, segundo Schlee (2008: 24):

“[...] refletindo o pensamento urbanístico da época, não avançou no sentido de reconhecer a existência de um patrimônio que teria de ser considerado preservado. Então, em 1980, com boa parte de prédios, casarões e fábricas em processo de degradação, é a partir do II Plano Diretor, que foram introduzidas as zonas de Preservação em Pelotas. No entanto, somente em 2008, na criação do III Plano Diretor de Pelotas, tendo em vista a estratégia para manter em harmonia as políticas urbanas com as políticas de patrimônio, que se estabelecem Áreas Especial de Interesse Cultural (AEIC), sendo a Zona Portuária da cidade, um deles." 
Em consonância com estas políticas urbanas e patrimoniais, há uma grande gerência e concessão deste patrimônio fabril na Zona Portuária, sendo revitalizado e tornando-se usufruto para a instalação da Universidade Federal de Pelotas (UFPel). A cidade, então, reforça sua posição de referência como polo educacional superior da região do extremo sul do Estado, bem como do Brasil, atraindo grupos de outras regiões do país. É percebido que, a partir destas transformações temporais no bairro e na cidade, são produzidas diferentes escalas temporais que refletem movimentos e passagens como entre o rural e o urbano. Na sua diversidade o bairro agrega diferentes grupos de moradores, possibilitando múltiplos ritmos de observação.

No sentido de produzir esta observação mais 'atualizada' sobre a temporalidade do bairro, o enfoque desta pesquisa ancora-se entre os dois últimos períodos que evidenciam a constante mutação do bairro, na passagem entre o período fabril agroindustrial e um polo universitário. Para prover este encontro temporal do bairro, trabalhamos a partir dos estudos da memória e da duração com a observação etnográfica.

\section{A poética da experiência: memória, cotidiano e temporalidades.}

Entretanto, é importante refletirmos acerca das ondulações temporais, não diferentes do que encontramos no bairro, pois, conforme escrevem Rocha e Eckert (2005), há diversas rupturas na formação social do Brasil que acarretam diretamente sobre os corpos coletivos que se desdobram para questões de consciência e ética, de uma sociedade que pouco conhece sobre seus processos históricos de fato e pouco tem a chance de conhecer por conta de um grande sistema político humano que negligencia estes acontecimentos. Daí as diversas rupturas, e a grande dificuldade que se tem que inserir novamente no cotidiano, na história, na memória e no aprendizado questões necessárias de serem reverberadas amplamente.

No trabalho de Tim Ingold (2005) intitulado "Jornada ao longo de um caminho de vida: mapas, descobrir-caminho e navegação" publicado e traduzido pela Revista Religião \& Sociedade em 2005, a antropóloga Clara Mafra introduz na apresentação da obra do autor, que a poética pode servir como uma das formas de percepção do ambiente

e dos produtos da imaginação humana. É uma tentativa de observar a cidade como um dos ambientes dessas produções poéticas, como uma chave de análise sensorial que pode ser entendida a partir da biografia dos citadinos por meio da qual as "narrativas na e da 
cidade brasileira apontam para essa sensibilidade das experiências biográficas dos contextos nas trajetórias singulares dos habitantes" (Rocha; Eckert, 2005: 25). Esses relatos e narrativas que; como já mencionado, também demarcam uma temporalidade e um território. Ao passo que também pode servir como esboço para buscarmos demais pistas e respostas a partir da formação deste emaranhado de coisas, sentimentos, subjetividades, conflitos, alianças, negações, fluxos, objetos, pessoas, são produzidas as cidades brasileiras:

\begin{abstract}
"Do hedonismo popular as produções de uma cultura artística de elite, do espetáculo político as paradas eleitorais, das celebrações dos calendários esportivos e musicais a festas religiosas, da exacerbação do corpo em espetáculo as delicias do consumismo, da proliferação de seitas religiosas e cultos a ressurgência de movimentos regionais e locais." (Rocha; Eckert, 2005:. 26).
\end{abstract}

Portanto, a cidade e o bairro precisam ser vistas enquanto materialidades temporais, por meio da busca dialógica para compreender o espaço entre suas destruições e construções, entre ordenamento e negação de sua constituição, até um "giro interpretativo considerando a cidade sob o plano de sua fenomenologia existencial" (Rocha; Eckert, 2005: 88) conferindo-lhe dimensões sensíveis sobre o habitar territorial no cotidiano. A materialidade aqui colocada em jogo serve para pensarmos uma antropologia urbana, visto que se coloca também sobre o viés da sensibilidade dos corpos, do movimento e das subjetividades inseridas em determinados contextos em que são criadas as cidades.

\footnotetext{
"Indiferente ao desaparecimento dos referentes materiais não mais dos espaços, mas sim, dos lugares, sobre os quais os grupos e indivíduos fundam suas identidades - seja mobilidade residencial, remoção de bairro antigos, transformação espacial e destruição urbana - , a cidade em sua polissemia, torna-se o testemunho dos jogos da memória de seus "agentes", espaço fantástico onde podem "colar" sua existência a certos momentos de interação social ali vividos em seus territórios e investi-los do próprio ritmo construído no corpo da duração de biografias de vida" (Rocha; Eckert, 2005:. 88).
}

Assim, o tempo social do Brasil (Freyre, 1959), conforme novamente as autoras nos informam, fornecem pistas para percebermos que viver na cidade pode ser entendido como "um ato de se arrumar, encadear e encaixar as diversas estruturas temporais e espaciais das trajetórias e histórias de grupos humanos que nela habitaram, em um esforço para estabelecer um tempo humanitário que se solidarize com a tarefa de seus habitantes de construir uma durée" (Rocha; Eckert, 2005: 90). Entendendo assim essa durabilidade - a partir das práticas e habilidades dos indivíduos e coletivos em 
consonância com uma época ou com um tempo - na duração da interpretação das vidas humanas, compreendendo a noção e especificidades de cada contexto inserido pelos seus habitantes.

Essas sobreposições são pertinentes para pensarmos como a narração da vida urbana modifica o próprio sujeito. Em suma, podemos destacá-la como um dos objetivos deste trabalho realizado na região do Porto, tendo como propósito analisar como determinados fenômenos urbanos narrados e situados pelos seus moradores formulam sentidos constitutivos na produção da diversidade dos territórios habitados.

Podendo ser compreendidos entre percepções, sensações, motivações que o bairro evoca em determinados habitantes e momentos a fim de propor uma outra leitura urbana focalizada em microações locais por meio do tempo social do bairro. Nessa justaposição entre narrativas, escolhas, momentos e conflitos, é que se localiza a consciência, bem como a disputa sobre a memória recai no posicionamento político, forjando estratégias de pertencimento identitário ao local habitado, conformando campos (territórios) de disputas de narrativas.

\section{Etnografia da duração no bairro do Porto: Agentes empíricos e suas trajetórias}

Partindo de uma "durée" ou uma durabilidade atrelada a temporalidade vivenciada no bairro, iniciamos nossa exposição etnográfica baseada em experiências de agentes empíricos que informam e dão forma ao bairro do Porto. Na transição temporal baseada em sociabilidades vividas e no jogo das memórias é que vão se desenhando e articulando maneiras de habitar no tempo da cidade.

Neste sentindo, há uma procura específica de forma a compreender que existem inúmeros bairros do Portos trilhados ao longo do tempo em diferentes formatos de interpretação. Não queremos, nem pretendemos ou muito menos ousamos tentar esgotar esta prática, mas procuramos uma interpretação sobre o que estas histórias, estórias e alegorias, nos dizem sobre possibilidades de vivenciar o Porto em seus múltiplos ambientes temporalizados.

Desta forma, propomos pensar a formação do bairro na condição dos atores que habitam a cidade, dentro de um contexto de complexidade da própria condição do bairro em suas diferenças. Iniciamos nossa observação por meio da narrativa de Jonas Santos, descobrindo caminhos com base na sua experiência, que retorna a ambientar uma Pelotas dos excluídos, das margens étnicas de seu povo, proveniente da diáspora negra, que a 
região situa e ambienta. Interpretada e rememorada pelo próprio Jonas, mas também agenciada nas narrativas pelos seus antepassados e familiares, na forma do agente empírico constituído como um herdeiro urbano destas memórias.

A partir destas percepções elencadas que podem categorizar inclusive uma cidade 'física', atrelamos a esse condicionamento a experiência vivida de alguns atores dentre os diversos atores-moradores do bairro do Porto. Entendemos estes como agentes na própria consolidação de sua noção sobre o bairro, quando transpassam limites e fronteiras estabelecendo as mais diversas dinâmicas entre ser morador, operário, sobrevivente, portuário e universitário.

Por meio da habilidade de Jonas de conhecer a região e determinados lugares dentro do próprio do bairro, no qual "descobre-caminhos" com o seu viver portuário. Partindo de suas redes sejam de sociabilidade, de convívio familiar e de parentesco, até momentos produzidos pelas situações ordinárias que se ampliam em sua percepção do bairro como um lugar de conflito, reconhecemos em sua narrativa a busca de reconhecimento identitário e pertencimento que o bairro representa para um determinado grupo étnico. Ao longo dos próximos passos de leitura traremos trajetórias e histórias que desenham e apontam para uma metamorfose do bairro constituído de industrial-operário ao universitário.

Começamos ao longo da metade do ano de $2017^{12}$ até o início de 2019 a realizar incursões de campo no bairro do Porto que se destaca atualmente pela movimentação dos polos universitários no bairro com suas atividades noturnas juvenis em bares e lugares de sociabilidade espalhadas pelo bairro Porto.

A partir de colegas, amigos e próximos que conheciam e até mesmo frequentavam em algum grau as atividades mais atualizadas da região, a proposta consistiu na formação de redes de interlocutores em torno deste objeto como ponto de partida para obter informações. O planejamento inicial tinha como objetivo realizar um campo narrativo com pontos de vistas diferentes sobre o bairro desde ex-moradores, moradores atuais e até (novos) frequentadores do bairro. Numas dessas idas e vindas no trabalho de campo por meio das redes de interlocutores criadas, obtivemos o contato de Jonas Santos, um ex-morador do bairro, atualmente artista visual e quadrinista que mora na Zona Norte de Pelotas.

\footnotetext{
12 O trabalho de campo está baseado na experiência etnográfica de um dos autores entre os anos de 2017 a
} 2019. 
A partir da narrativa e da memória deste ex-morador, notou-se em sua fala política sobretudo, uma região portuária negra que remetia a suas sociabilidades e seu convívio familiar como habitante do bairro. Jonas Fernando Martins dos Santos, nascido no início da década de 1970, em Pelotas, vem com seus pais, Rubens Gilberto Cardozo Santos e Adélia Martins Santos, de uma comunidade Quilombola ${ }^{13}$ situada no distrito rural da cidade de Canguçu e acabam se instalando na região do bairro do Porto para viver e trabalhar por volta dos anos 1950 em virtude da ampla oferta de trabalho fabril-operária da época.

Na sua infância, tem o início do "marco portuário" no bairro quando foi morador da comunidade do Rosário ${ }^{14}$, bem como a partir do Colégio Espírita de Ação Assistencial Dona Conceição, que fomentava determinadas atividades recreativas e escolares na região. Foi também morador da Coreia e do Gasômetro. A Coreia hoje em dia não existe mais fisicamente, por conta dos deslocamentos produzidos pelos moradores do lugar, além da instalação de novos anexos industriais que foram construídos na vegetação formada, conforme mostraremos ao lado na imagem. No entanto, segundo Jonas, é possível detectar o espaço a partir dos rastros deixados pelos trilhos que demarcam o lugar.

\footnotetext{
${ }^{13} \mathrm{O}$ termo quilombo está vulgarmente vinculado a organizações comunitárias autônomas de escravos fugidos que se estabeleceram entre os séculos XVI e XVII no Brasil afim de resistirem à condição de escravidão. Porém, o termo ganha significados muito mais extensos ao vincular-se às questões socioculturais que envolvem o direito população afrodescendente a direitos no Brasil, entre eles o da terra. Como coloca Leite: "O quilombo (...) na atualidade, significa para esta parcela da sociedade brasileira sobretudo um direito a ser reconhecido e não propriamente e apenas um passado a ser rememorado. Inaugura uma espécie de demanda, ou nova pauta na política nacional: afro-descendentes, partidos políticos, cientistas e militantes são chamados a definir o que vem a ser o quilombo e quem são os quilombolas". (Leite, 2000: 335)

${ }^{14}$ Historicamente, a criação por volta da década de 1880 , momento que se constituiu também no início da campanha abolicionista na cidade. Havia, ainda, a Irmandade da Santíssima Virgem do Rosário, entidade católica criada anteriormente. Para mais informações, ver Beatriz Loner e Lorena Gil (2009).
} 
Figura 9 - Antiga Rua da Coréia ao fundo do arvoredo, 2017.

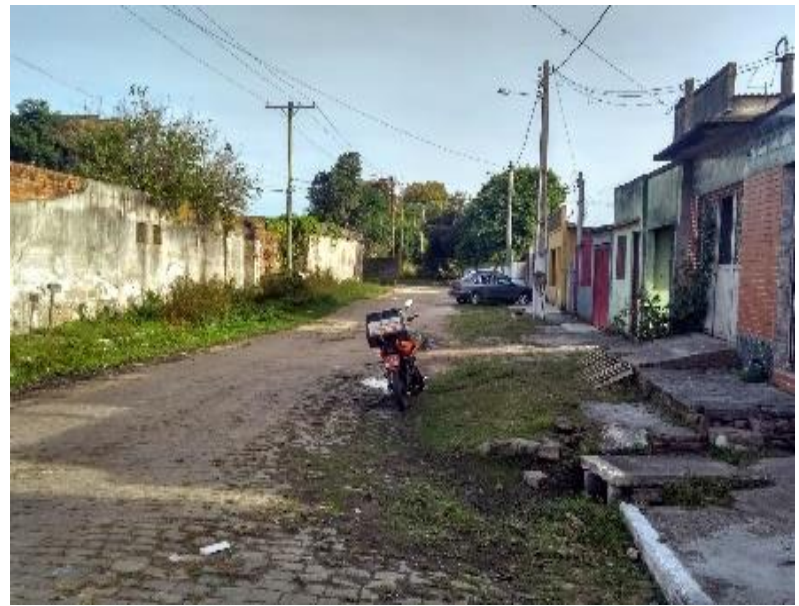

Fonte: Acervo dos autores.

Figura 10 - Sociedade Espírita Dona Conceição, ainda funcionando como escola, 2017.

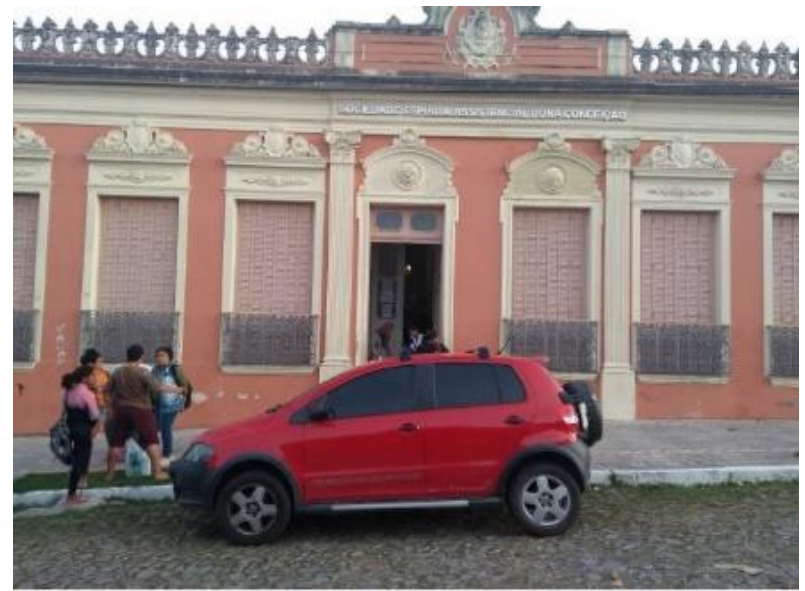

Fonte: Acervo dos autores.

A partir do seu "descobrir-caminhos", acaba produzindo determinadas habilidades de transitar e habitar pela região, onde nos coloca de forma lúdica, através da elaboração de seus mapas para relembrar esta própria temporalidade. Além desta estratégia narrativa e nativa, utilizamos no texto abaixo para situar os leitores deste contexto produzido num determinado espaço de tempo. Os mapas contem nome das ruas, legendas dos equipamentos que faziam parte do bairro.

Situado ao fundo da Rua Santa Cruz (ou na frente, se partimos da perspectiva de que a formação da cidade se inicia aqui), atrás da mureta lá no fundo da imagem cercada pela alta vegetação, situava-se a vila da Coreia e, mais atrás ainda, quase não podendo ser visualizada na imagem, há a Usina do Gasômetro. 
Figura 11 - Residências antigas portuárias e elevação do asfalto, 2017.

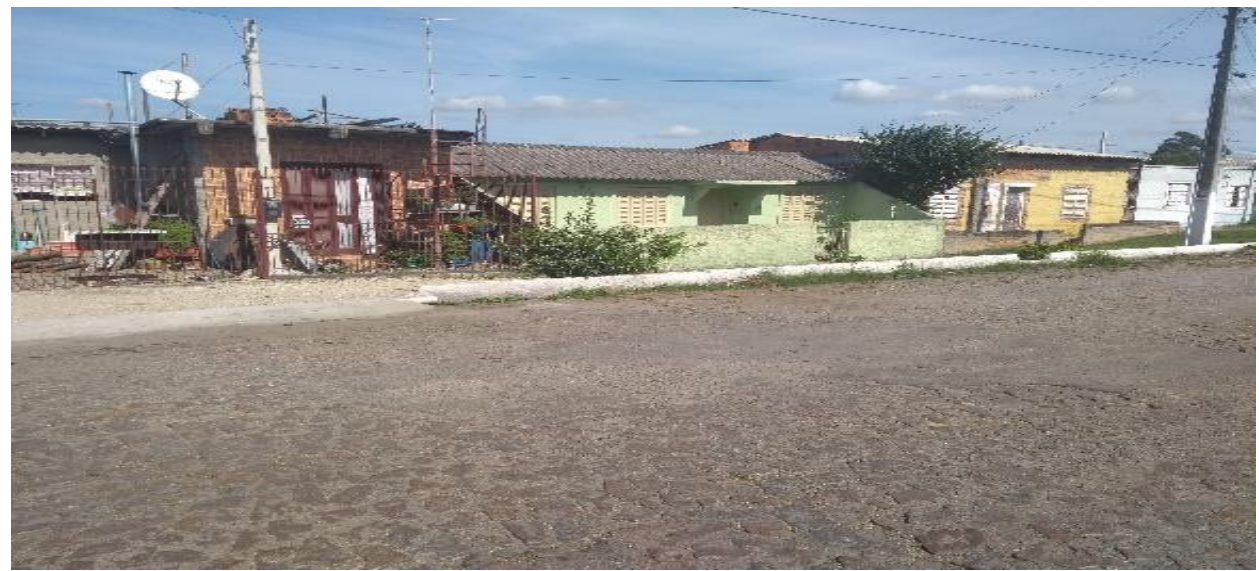

Fonte: Acervo dos autores.

Além destes rastros, foi possível encontrar vizinhos próximos daquela época, como a Dona Oraida e seu filho Rudi, endossando a narrativa de Jonas, por meio de um consenso memorial, com base em suas conversas identificando certas características que conformavam o lugar e o bairro na determinada temporalidade narrada. Ambos, faziam parte da rede de relações da família de Jonas na Coreia. Dona Oraida mora há aproximadamente 50 anos na mesma residência, (somente foi modificada a estrutura da casa de chalé de madeira para o cimento) hoje com 80 anos.

Em uma das conversas com Jonas, quando presenciei o compartilhamento da memória coletiva a partir de alguns eventos do bairro, Dona Oraida lembrou da intensidade com que o trem passava ao lado de sua casa, trazendo inúmeros relatos da entrada no bairro por meio de cargas de insumos primários como cimento, areia, além de produtos alimentícios como o pescado, arroz e farinhas embarcados de Pelotas até Rio Grande, entre idas e vindas pela Ponte do Ramal. Os eventos que faziam parte do cotidiano destes moradores demonstravam a imagem provedora do cenário daquele tempo, com base nos quais lembravam também a grande quantidade de fábricas e indústrias situadas no bairro, ocasionando a geração de uma enorme empregabilidade para os moradores mais necessitados da região portuária.

Figura 12 - Jonas, Dona Oraida e seu filho Rudi, 2017. 


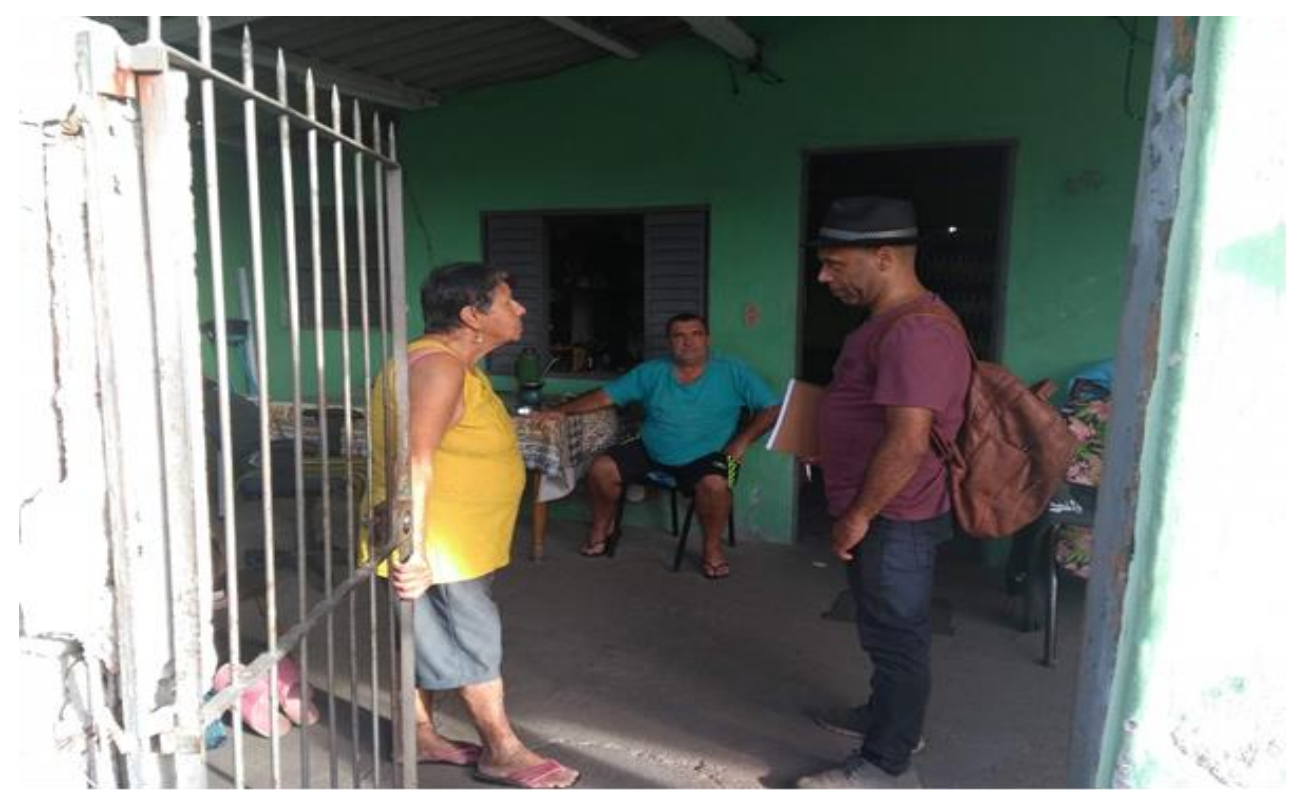

Fonte: Acervo dos autores.

Um elemento interessante que pode esclarecer o reconhecimento do bairro como um lugar com o histórico de marginalização tem a ver com a sua localização citadina. Ao perguntar para Dona Oraida se notava alguma modificação em relação ao lugar que morava, sem que fossem as relatadas sobre o trem e fábricas, ela apontou uma mudança significativa em relação a localização geográfica da cidade, situando que o bairro agora faz parte, administrativamente, do Centro e não do Porto. Relata: "Aqui na conta de luz parece Centro, e não Porto, então moramos no Centro, né? É bem próximo”. Jonas, por sua vez, me relata que a estigmatização histórica do bairro revela uma certa marca pejorativa e receio ao nome Coreia e demais vilas, por ter sido um lugar de muita pobreza e miséria.

Outro ponto que conformava o espaço estigmatizado são as atividades que conotavam, e conotam até os dias de hoje, a marginalização, como a proximidade com o prostíbulo, conhecido como Maria das Tetas. A cabo de explicação, julgo o nome peculiar ser autoexplicativo, conforme também Jonas relatou. Este prostíbulo funcionava na Rua Santa Cruz, que ficava nas mediações da Coreia, assim como havia outro próximo da Rua João Manoel. Em um entendimento mais amplo, o relato importante do prostíbulo pode ser entendido tanto como uma atividade fonte de renda para as mulheres na informalidade, quanto um ponto de encontro para atividades sexuais. Jonas rememora, de sua infância, o grande movimento e fluxo de trabalhadores nesta região que, como mencionado, era próximo da Coreia. Complementa: 
"Essa rua aqui, tu via os caras tudo sentados nos meios fios da calçada. Era lotado, meio dia, então". Nesta passagem pelos prostíbulos que conformavam o bairro, podemos encontrar as casas até hoje. (Jonas Santos, 2018).

Figura 4 - Prostíbulos chamados de Maria de Tetas, 2017.
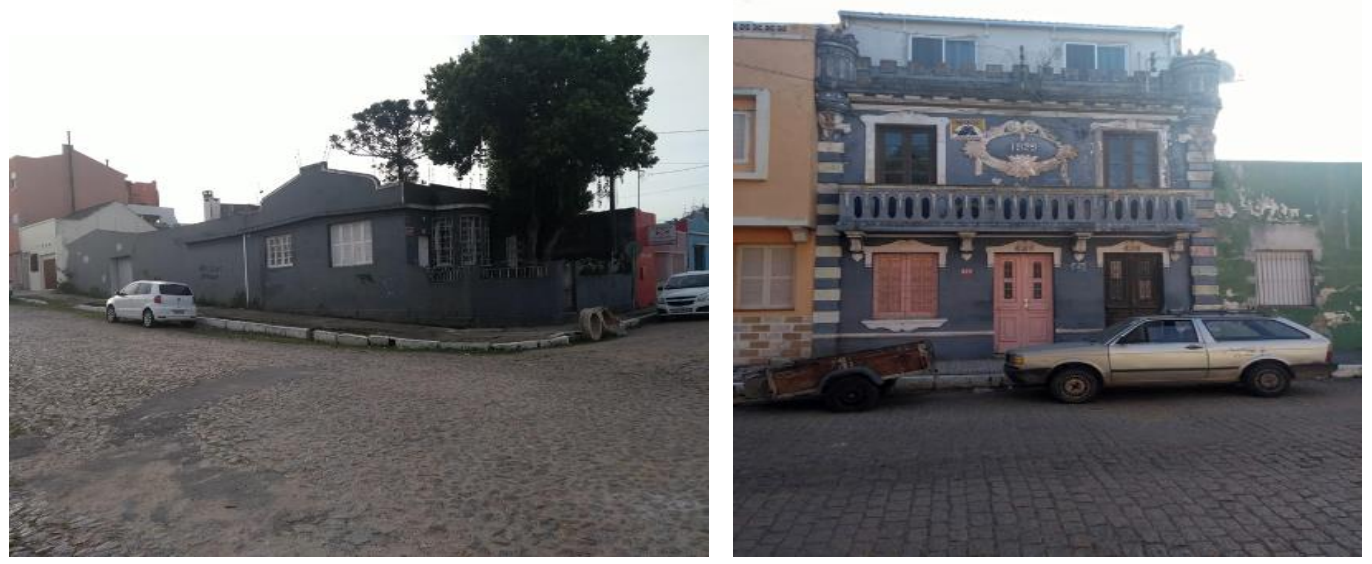

Fonte: Acervo dos autores.

As duas últimas referências são importantes para situar a narrativa de Jonas e o contexto que busca rememorar. Outro fator relevante que remete a esse contexto pode ser visto nas caminhadas com Jonas, ao apresentar uma região formada por uma grande presença de Quilombos urbanos. Conforme já relatado, a região portuária serviu também como fornecedora de gás ${ }^{15}$.

A partir do Gasômetro, em meados de 1910, o gás era fornecido por meio do encanamento para o centro da cidade Além disso, por volta dos anos 1940, existiam os cabungos ${ }^{16}$, serviço realizado ainda no bairro a partir da coleta de dejetos humanos, como fezes, de casas que não possuíam encanamento. Serviços estes realizados pelos cabungueiros, quase sempre negros. Tratava-se de uma possibilidade encontrada a partir dos subempregos existentes no período pós-charqueadista e escravocrata da cidade. Após a coleta, os dejetos eram 'escoados' no canal São Gonçalo ${ }^{17}$.

\footnotetext{
${ }^{15}$ A respeito deste assunto, para mais detalhes, ver Axt (2012).

${ }^{16} \mathrm{O}$ cabungo ou cubo era um pequeno barril cônico de madeira de aproximadamente cinquenta centímetros de altura, com a boca de mais ou menos vinte e cinco centímetros, chegando a sua base com trinta e cinco centímetros, que semanalmente era substituído pelo Asseio Público (atualmente conhecido como a prestação de serviços como limpeza urbana), que os levava em carroças puxadas por cavalos percherons, melhor alimentados que os pobres e desgraçados homens que tal serviço faziam. Fontes narradas pelo livro de um dos ex-moradores do bairro do Porto, Luiz Guterrez, vindo da cidade de Capão do Leão, finais da década de 1950. Para mais detalhes sobre trabalhos específicos, ver Simões (2017) e da Rosa Machado (2010).

${ }^{17} \mathrm{O}$ canal São Gonçalo margeia a cidade de Pelotas e liga a Lagoa dos Patos à Lagoa Mirim.
} 
Figura 5 - Despejo de fezes no Rio São Gonçalo em 1940.

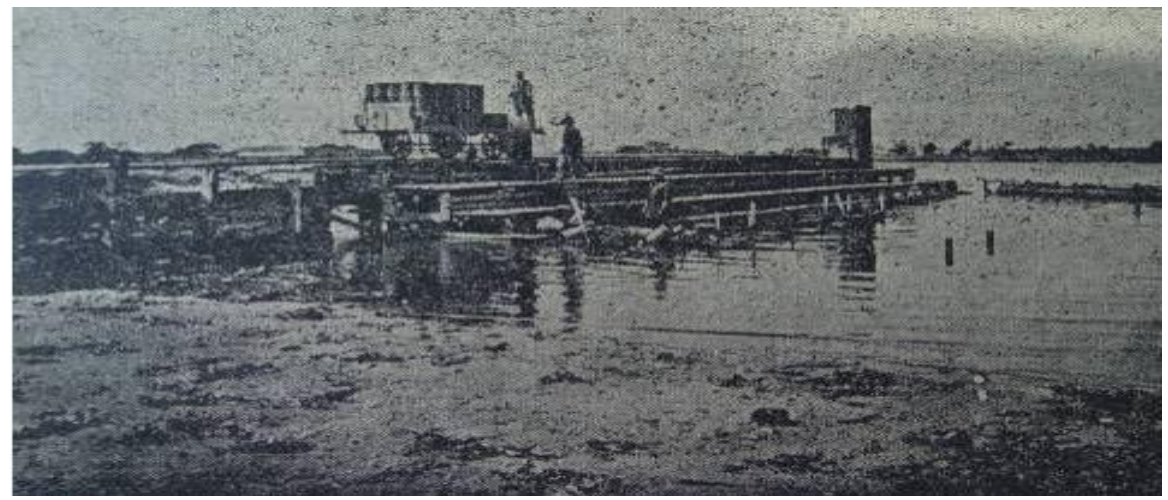

Fonte: Janaina Xaiver, 2010.

Entre este grande cenário não oficial que reserva o bairro do Porto, é possível evidenciar, se estivermos atentos, aos vestígios da enorme herança destes Quilombos concentrados na região portuária.

Em uma de nossas caminhadas pela região, na vila da Dragagem da Várzea ${ }^{18}$, nas proximidades da Coreia, Jonas, ao ir relatando os lugares que foram marcantes em sua vida portuária, também fez questão de trazer as demais pessoas que fizeram parte desta passagem coletiva pelo bairro, bem como me levou para encontrar alguns antigos moradores. Um deles se chama Mário, mais conhecido como Marinho D’ Xangô, pertencente e fundador da Casa Religiosa Agjandú Luá, da Nação Cabinda, em atividade na região do Porto, desde 1975. Em sua conversa sobre o bairro a respeito das vizinhanças, redes familiares e eventos que aconteciam no bairro, um relato interessante foi que, ao lado da Casa Religiosa, passava o trem fazendo estremecer as moradias de toda a vizinhança, além de danificá-las, criando fissuras.

Entendemos como uma pista a presença de muitas Casas de Religião de Matriz Afro-brasileira e seus Templos espalhados ao longo do bairro pelas ruas Bento Martins, Uruguai, Dona Mariana, além da extensão da Dom Pedro II que desemboca no bairro Navegantes, bem como espalhados pela região central como a Santa Cruz, Major Cícero, Cassiano e Barão de Santa Tecla. Pelotas, se bem observada, é um cenário de muita produção literária local com o registro de muita produção sobre a cultura negra.

\footnotetext{
18 Outros nomes nativos que conformam toda a margem portuária em relação a Várzea, além dos que estamos trabalhando podem ser encontrados como Vila do Capaia, Vila da Caatinga e Vila da Casquinha.
} 
Figura 15 - Encontro com Jonas e Pai Marinho D’ Xango, 2017.
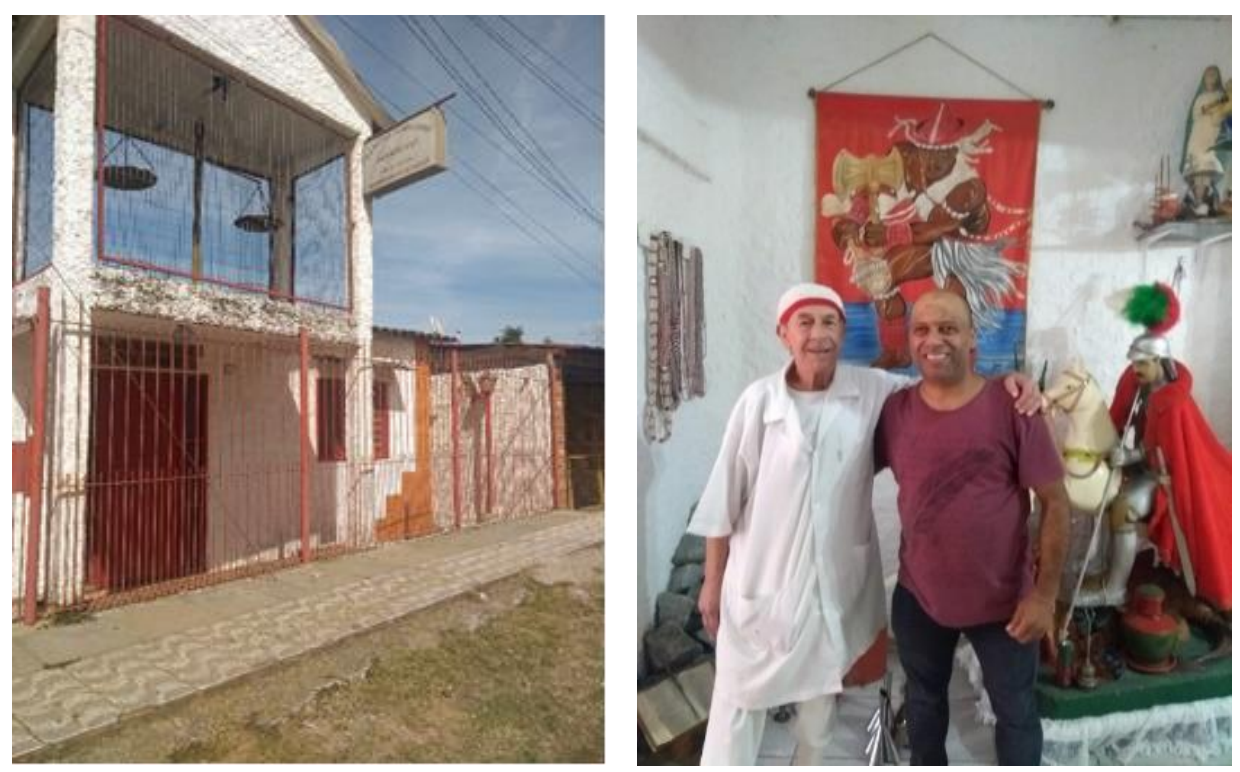

Fonte: Acervo dos autores

Dando respaldo para este cenário narrado pelo ex-morador do bairro, Jonas, apontamos também para a observação da pesquisa no bairro sobre as Casas de Religião Africana, do qual reflete e revela uma intensa presença do negro, além de suas sociabilidades inserida na religiosidade do cotidiano pelotense, identificada também a região do Porto como um ponto histórico de presença negra, a partir de suas diversas durações, iniciado no século XIX com as charqueadas na construção do baronato pelotense. Assim, o escritor local Adão Monquelat (2012) por meio de sua obra "Pelotas dos Excluídos" revela, entre dados históricos e romances, textos que ressaltam o período da escravidão na cidade, além de todo um cotidiano negro, tendo o bairro como aporte principal para estas produções que se atualizam no tempo desta pesquisa.

A Coreia concentrava-se nos pontos finais das ruas atuais, Santa Cruz e Gonçalves Chaves, desembocando até a ponte do Ramal. A explicação para o apelido Coreia, se dava por conta da grande concentração de famílias em condições precárias que se instalavam no lugar - por isso a derivação do nome faz referência a uma relação da situação em que se encontrava o país em meados dos anos de 1950 a 1970.

O nome Coreia, segundo relata Jonas, era sobretudo um termo pejorativo em razão da grande quantidade de moradores negros instalados em arrabaldes (hoje o termo mais atual seria vila ou periferia) na formação do lugar, assim como da criação e expansão do bairro para outras regiões da cidade, especificamente o centro e demais 
bairros periféricos próximos a região do bairro. Inseridos neste espaço urbano, eram vistos como não "pertencentes a condição de obter um status de cidadania na época, não participando da vida ativa da cidade". Ao relatar a estrutura e sistemas de moradia que eram produzidos em sua época, Jonas conta:

"Morávamos numa casinha na Coreia e no Gasômetro, que é um 'dois por dois' $(2 \mathrm{~m} / 2)$, um ' 3 por 3 ' $(\mathrm{m} / 2)$, que tu sabe, que tem gente que mora com a família de cinco, seis e até dez. Além das condições precárias de sobrevivência, enfatiza: "era uma região muita densa, o povoamento na Coreia, por isso também o nome".

A partir das caminhadas realizadas com Jonas, foi possível constatar a continuação temporal dos cinturões de miséria (periferias), habitada entre o arrabalde com o chão batido de terra, por meio da manutenção e preservação pelos próprios moradores, além da vegetação natural do local que ambienta o cenário permeado de barracos, chalés produzidos com o próprio material disponível do cenário, além de algumas casas mais padronizadas com cimento.

Figura 6 - Residencias na Vila da Dragagem, 2017.

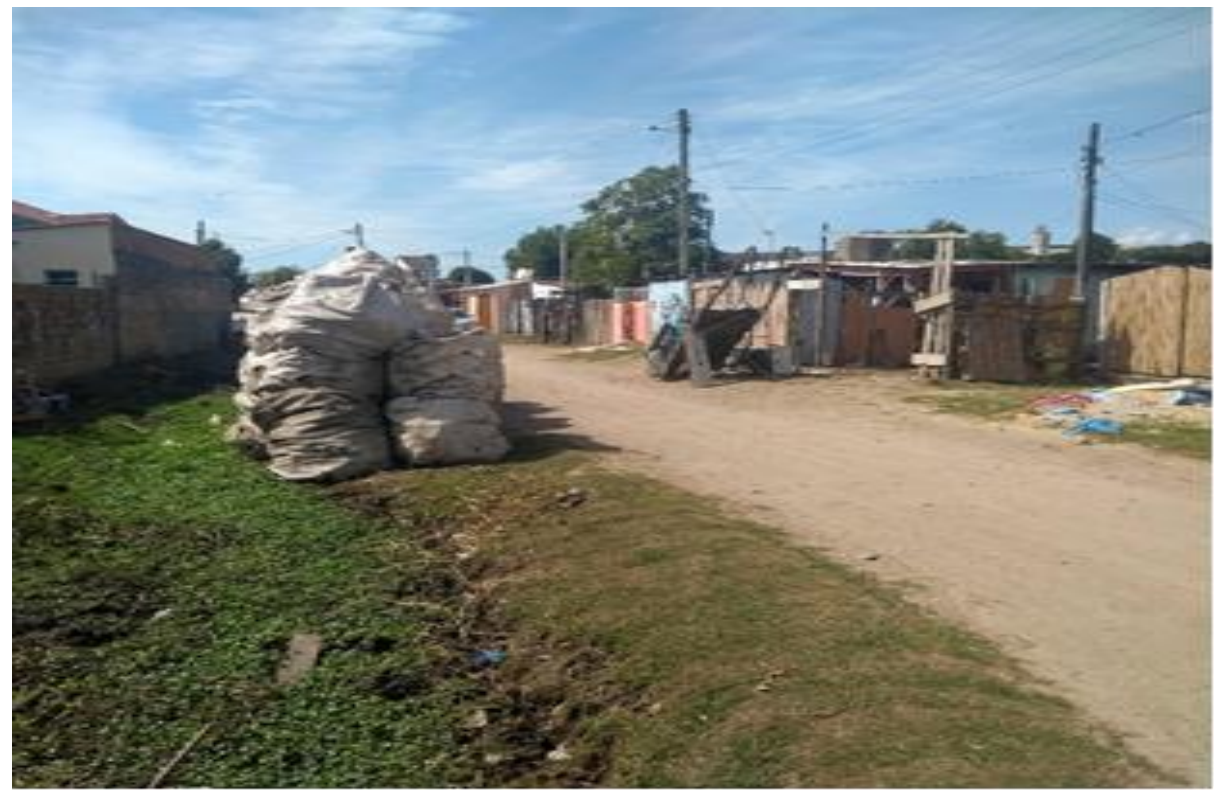

Fonte: Acervo dos autores.

A criação de animais como galinhas e cavalos também pode ser notada em função do amplo espaço natural que o local possui. Tais elementos configuram uma parte da paisagem e do cenário do bairro, situa Jonas em sua rememoração constante sobre os traços das casas e objetos que faziam parte do ambiente do lugar, configurando suas 
referências sobre o modo de enxergar a Coreia. Segundo Jonas, a Vila da Dragagem da Várzea relembra a temporalidade da Coreia.

Figura 17 - Casa na Vila da Dragagem, 2017.

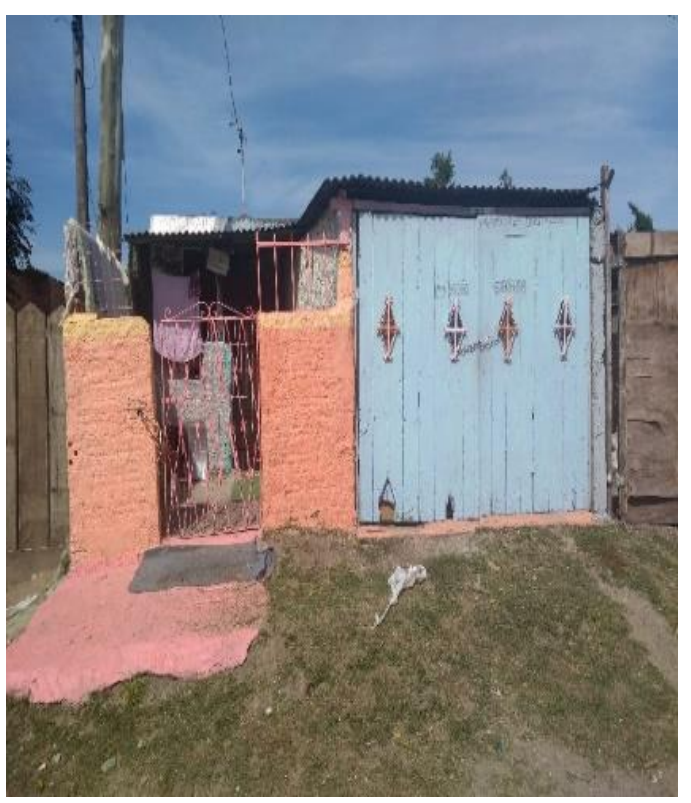

Fonte: Acervo dos autores.

Figura 18 - Empresa Olvebra, 2017.

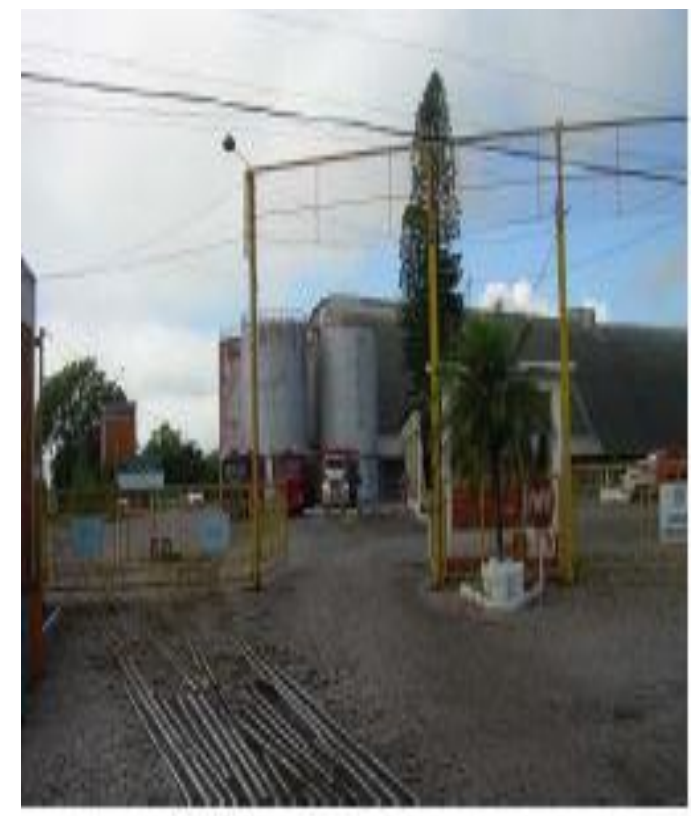

Fonte: Acervo dos autores. 
Essa região portuária pode ser constituída também como um bairro operário, a partir da intensa e ampla instalação de fábricas agroindustriais visando o rápido escoamento por meio dos atracadouros situados na região. Entre algumas das empresas, Jonas vai situando a composição industrial-fabril de seu tempo: Empresa de Óleo de Soja Olvebra/Indústria e Comércio, Empresa de Óleo de Soja Kasper/Indústria e Comércio, Empresa de Reciclagem de Plásticos Arteplast, Empresa de Drenagem de Canais Diques - Dragagem, Frigorífico Anglo, Empresa de Grãos Cosulagri, Indústria de Tecelagem Fiação e Tecido, Empresa de Produção Agrícola Sudeste, Agrotóxicos Sintesul, Depósito de Grãos Irga, Classificação de Lãs Cosulã, Distribuidora de Laticínios Cosulati, Empresa Pesqueira Leal Santos .

Já no destaque em relação ao trabalho especificamente portuário, Jonas recorda que há, pelo menos, cinco empresas terceirizadas que trabalhavam no embarque/desembarque como a Rede ferroviária Federal Sociedade Anônima - RFFSA, no transporte de grãos, carvão e combustível, Laboratório Leivas Leite ${ }^{19}$, Almoxarifados da Prefeitura (hoje o Serviço Autônomo de Abastecimento de Água de Pelotas), Silos de armazenamento Taurus, Máquinas Vitória e Sementes Plantar.

Esse relato das fábricas e indústrias no Porto é importante, pois evidencia como a constituição deste bairro operário e fabril aparece em sua história e biografia de morador, principalmente quanto à formação do bairro que entrecruza suas narrativas entre a fábrica, cidade e a sobrevivência. Essa relação da memória relatada se constitui a partir de seus pais sendo trabalhadores de uma região fabril agroindustrial e, sobretudo, região portuária, mas que, ao mesmo tempo, se abre em direção a outros bairros da cidade.

\begin{abstract}
"O meu pai trabalhou no Porto, na descarga dos navios, por pelo menos 10 anos. Nesse período, ele fazia outros trabalhos como mestre de Obras. A minha mãe trabalhou na Leal Santos, uma empresa pesqueira que embalava o pescado aqui em Pelotas, colocava nas latas. E a minha mãe trabalhou na indústria doceira, na Pomerania, na Vega e outras empresas doceiras aqui da cidade. Assim, meu pai trabalhou no porto, na Cibrazem, e o trabalho na Cibrazem
\end{abstract}

\footnotetext{
${ }^{19}$ Segundo Jonas relata, um marco tecnológico que constitui a formação arquitetônica do bairro na época é a inserção da técnica do cimento penteado. Como exemplo, apontamos uma destas características empregadas ao Laboratório Leiva Leites ainda em atividade na região. O cimento penteado é de uma época de transição entre o reboco a base de cal - utilizado na construção dos casarões neoclássicos - e o reboco a base de cimento. Esse é um dos motivos pelos quais você não vai vê-lo na fachada dos suntuosos casarões da volta da Praça Coronel Pedro Osório. O cimento penteado pode ser observado na Catedral São Francisco de Paula, no Colégio São José, no Castelo Simões Lopes, e no Theatro Guarany. Além destas grandes estruturas, o cimento penteado está presente em casas mais simples, porém não menos importantes na composição da paisagem urbana. O cimento penteado é uma técnica de construção, relativamente recente, utilizada na primeira metade do século 20. Cabe destacar também, o alto nível de elementos químicos concentrado em sua produção, manual, do qual ocasionou muitas doenças pulmonares e respiratórias em muitos trabalhadores, sendo o pai de Jonas um deles. Para mais detalhes, ver Salaberry (2011).
} 
acabou custando a vida dele. Porque era um trabalho muito insalubre em contato com o veneno, ele acabou sofrendo sequelas graves disso e vindo a falecer muito cedo por conta do trabalho com o veneno.” (Jonas Santos, 2018).

Por se tratar de um bairro agroindustrial, pegamos carona com as autoras que auxiliam a episteme deste trabalho (Belmonte, apud Rocha; Eckert, 1986) onde: "sabe-se que no ocidente moderno, urbano e industrial, a arte de ouvir e escutar era a mola propulsora que fundava os laços de sociabilidade pública nos arrabaldes arraiais e vilarejos, transformou-se progressivamente nos formatos de narrar a cidade".

Em um dos encontros realizados no Centro de Artes da Universidade Federal de Pelotas, Jonas, ao ser perguntando sobre questões de sociabilidade musical ${ }^{20}$, para além dos Clubes Negros e especialmente para os Clubes Carnavalescos Negros, afirmou que nessa região do Porto eram intensas.

Segundo Jonas, as suas práticas de convivência eram estabelecidas inicialmente na esfera individual, no familiar - a casa, a vizinhança - até a inserção coletiva, de sua juventude nos clubes sociais negros como o Chove e Não Molha, mais conhecido como “Chuva” e o Fica ahí P'ra Ir Dizendo ou "Ficahí”. Ambos fundados no início de 1920, em funcionamento até os dias de hoje fazem parte da constituição social negra presente neste território, constituído como espaços recreativos (Gil; Loner, 2009) que se desenvolvem a partir das suas relações com blocos carnavalescos e a música, em especial, o samba, na criação de agremiações de escolas de samba.

Figura 19 - Clube Social Negro Chove Não Molha, 2017.

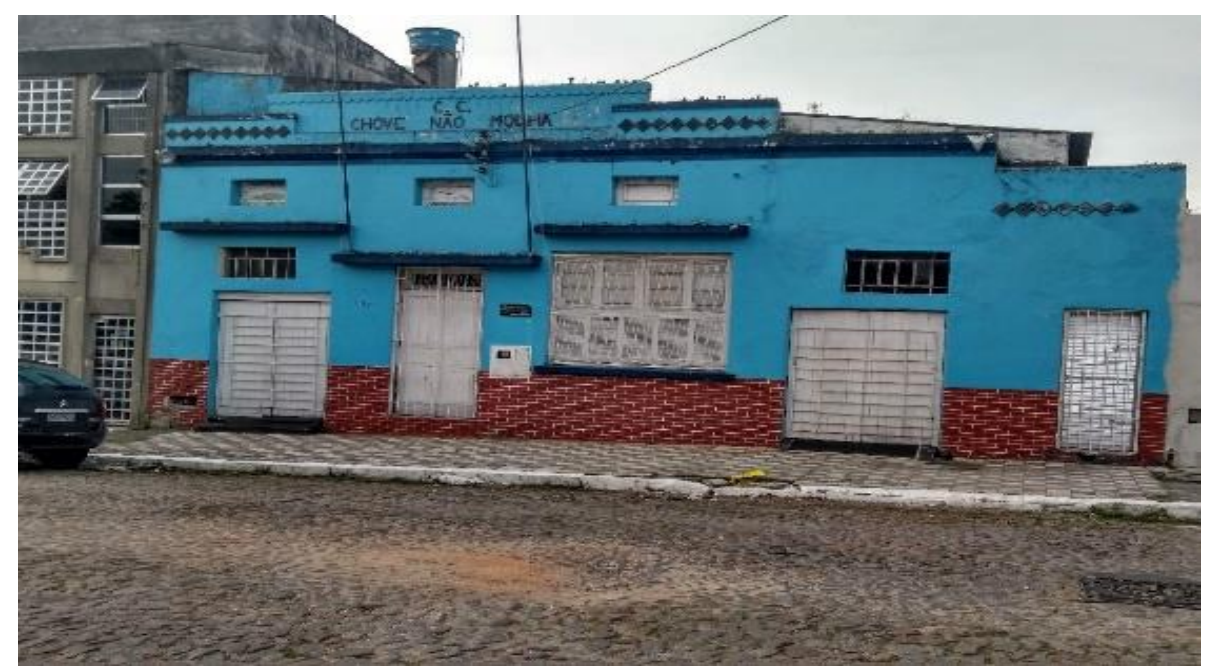

\footnotetext{
${ }^{20}$ Cabe destacar, que em alguns encontros e entrevistas coletivos com Jonas, tiveram a presença de colegas em pesquisas de outras áreas, como a de André Gomes, tendo a temática sobre etnomusicologia em Pelotas a partir do Samba e da relação de parentesco com seu avô, Zé da Cuíca, um dos grandes sambistas da cidade de Pelotas.
} 
Fonte: Acervo dos autores.

No surgimento e fundação dos times de futebol do bairro, indo até os bailes escolares, o chamado ginásio ${ }^{21}$ com o surgimento de estilos musicais da cultura negra, ou a música Black ${ }^{22}$, como o próprio Jonas denomina em um determinado momento de sua adolescência. Assim, a trajetória rememorada como pertencimento e identidade era reforçada nesse período de sua vida.

Já no âmbito do futebol, na sua adolescência percorria toda a região portuária disputando os campeonatos de várzea promovidos pelas diversas entidades fabris e agremiações fundadas pelos operários. Algumas delas, como o São Gonçalo ou atualmente conhecido como Osório Futebol Clube (Osório F.C), no Passo dos Negros, criadas a partir da relação dos trabalhadores e moradores com o local de trabalho Engenho São Gonçalo. Existia também o Esporte Clube Fiação e Tecidos, fundado em 1954 pelos operários da Companhia de Fiação e Tecidos. Jonas jogou tanto pelo Osório quanto pelo Nacional Futebol Clube, fundado em 1956. Ambos ainda em funcionamento.

Figura 20 - Sede do Osório Futebol Clube, 2018.

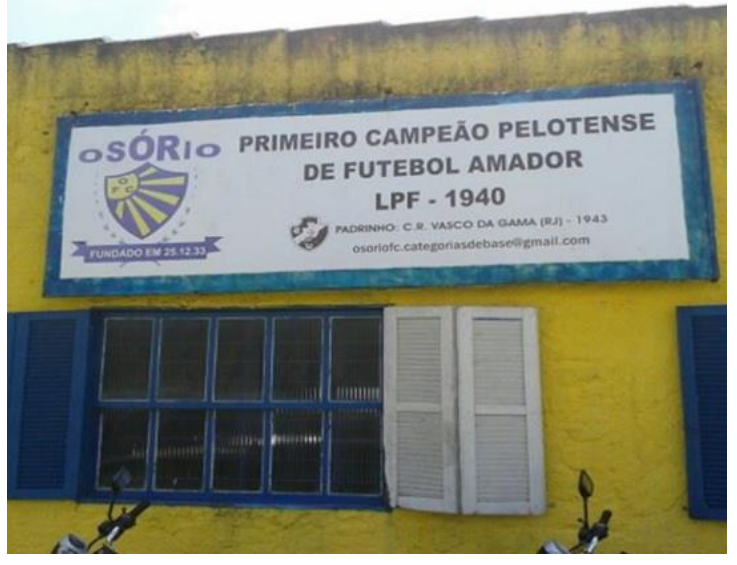

Fonte: Acervo dos autores.

Figura 21 - Sede do Nacional Futebol Clube, 2018.

21 O termo ginásio refere-se à escola, especificamente ao ensino secundário ou Ensino Médio, como é conhecido atualmente.

22 Ou conhecida como Black Music. É um termo que abrange música produzida ou inspirada por pessoas negras, incluindo tradições africanas musicais como a música popular africana, bem como os gêneros musicais da diáspora africana, incluindo música afro-caribenha e música afro-americana 


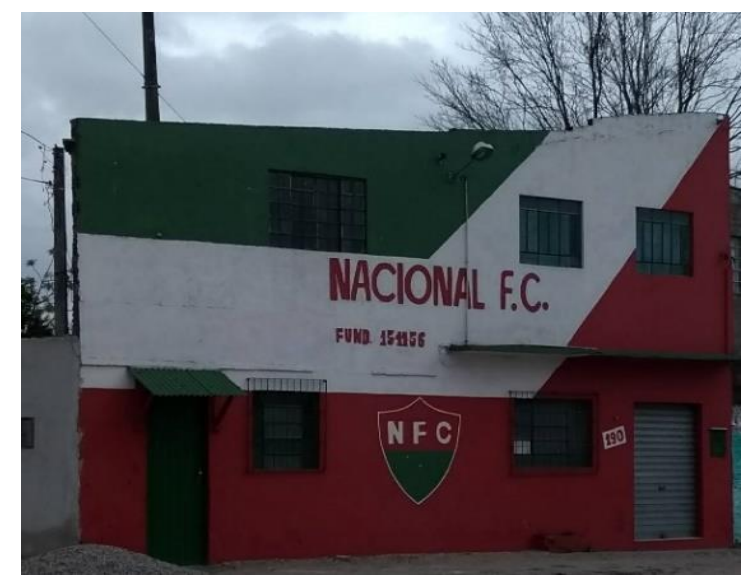

Fonte: Acervo dos autores.

Além destes citados, Jonas jogou em alguns outros clubes ${ }^{23}$ como a Associação Atlética Ponte Preta, Sport Club Ouro Preto, Roma Futebol Clube, São Jorge Futebol Clube e Vasco da Gama, do bairro Navegantes; e Esporte Clube Nossa Senhora de Fátima, atualmente bairro Fátima. Ambos, bairros oriundos da região do Porto. Na Coreia, relata Jonas, foram fundadas as equipes Santa Cruz e o Tiradentes mais para o lado da várzea, além do Bota N’Agua, na metade dos anos 90. Os campos de futebol onde se realizavam as partidas ficavam no Castelo do Major ${ }^{24}$, tendo os jogos oficiais, atualmente, nas mediações iniciais da Rua XV de Novembro.

Já no espectro da sociabilidade familiar, sua relação começa dentro de sua casa, na esfera privada, inserido na Coreia, pois relatou que sua Vó, Maria de Lurdes, cantava na Rádio Pelotense. A propósito, a Rádio em atividade mais antiga do Brasil. Tal passagem, por sinal, situa o contexto urbano-industrial e cultural a partir do consumo e fruição dos aparelhos tecnológicos da época, por meio dos programas radiofônicos e, mais tardiamente, a inserção da televisão colorida nos anos 70 no Brasil.

\footnotetext{
${ }^{23}$ Como se pode perceber, há uma reprodução do nome dos times oficiais fundados nos bairros de Pelotas. Segundo uma visitação realizada na sede do Clube Osório, no Passo dos Negros, da qual seu presidente e membro fundador, seu Aníbal, relata que a menção a estes times era exclusivamente em virtude de seu prestigio nacional na época, sendo assim, uma forma de homenagear estes clubes. Times estes, fundados sob o espectro português. Como o próprio Osório, apadrinhado pelo Vasco da Gama. Além das cores do Nacional, 'tricolor' marcado pela coloração do time do Fluminense, ambos cariocas e fundados numa temporalidade marcada pela formação da República no Rio de Janeiro.

${ }^{24}$ Segundo Osório Magalhães (2007), a resposta leva à excentricidade de um militar e fazendeiro gaúcho com pendores sociais e artísticos. O terreno pertenceu ao major de exército Antônio Duarte da Costa Vidal, que lutou na Guerra de Canudos (1896-1897), no nordeste baiano, e uma vez reformado fixou residência em Pelotas e fez construir o "sobradão" segundo um modelo europeu (castelo da Baixa Idade Média, séculos XI-XV). Conforme escreve o autor, o major Vidal já era proprietário de grandes terras na fronteira oeste do Estado (cidade de Itaqui), comprou o dito terreno da Quinze de novembro em 1931 e mandou construí-lo, em 1936 - o que ocorreu em etapas, pois ele viajava muito. Edificou outro parecido em Itaqui, hoje também abandonado.
} 
Jonas releva que foram criadas algumas medidas estratégicas para fazer parte desse grupo. Assim, noções de solidariedade e sociabilidade eram produzidas internamente no âmbito do lazer familiar, inseridas de forma caseira e também a partir do compartilhamento da casa, no compartilhamento da sala com os demais moradores do beco, como também era chamado. Em sua infância, habitante da Coreia, relata que havia em torno de aproximadamente quinze a vinte famílias.

Com isso, mostra-se o partilhamento de uma sociabilidade comunitária que marcou a passagem de uma temporalidade na vida de Jonas dentro do espectro familiar, como as formas de assistir TV, sendo um momento de união. Além disso, existiam algumas técnicas de criatividade produzidas para adaptar a sua realidade local a fim de prover o exercício de um cidadão da época:

[...] Televisão Caravelho (TV preto e branco) - a televisão foi adaptada na sala para que as outras pessoas do beco pudessem ir assistir televisão junto. $\mathrm{Na}$ televisão, colocávamos papel celofane - para fazer ficar colorido. Assim se tinha a casa cheia, tinha um senso de coletividade, de divisão.... Daí que vem o senso da cultura do dividir... de propagar nas periferias. (Jonas Santos, 2018).

Situa ainda a criação de profissões como a do engraxate, que se deslocava da região portuária até as partes centrais da cidade. O pai de Jonas foi um deles, que, além de desenvolver o seu trabalho, o de engraxar os sapatos, também se colocava em uma relação com a música e o samba: "Os caras jogavam uma moeda para ele [engraxate] fazer um samba na hora".

Jonas conta que quando seu pai chegava em casa após uma longa jornada de trabalho, "pegava uma caixinha de fósforo e fazia um 'sambinha', e minha vó cantava, e nós dançávamos, já fazia tudo dentro de casa. Tudo em casa.” Em relação a sociabilidade musical, presente em suas práticas portuárias, Jonas relata a participação de seu pai com os blocos carnavalescos, passando pela sua relação com o trabalho portuário a partir suas atividades de descarregamento de mercadorias. Esta atividade de descarregamento, como seu pai lhe contava, também era vista como um 'lugar para fazer música'. Não obstante, a musicalidade era entendida também como um momento do descanso e de certa expressão cultural étnica ${ }^{25}$, entre uma pausa e outra do descarregamento.

\footnotetext{
${ }^{25}$ Uma pista para podermos interpretar estes acontecimentos, são nas palavras de White e White (2005) o "som do cativeiro". Além disso, Abreu (2015:78) aponta que canções escravas foram parte estruturante das sociedades escravistas americanas. Envolveram-se com as políticas de controle e repressão de senhores e autoridades, e com as estratégias de resistência e negociação dos escravos. O "som do cativeiro" era
} 
Uma pausa, também, para observamos o léxico temporal agenciador de determinada organização social que produz diferentes sentidos: descanso, tempo livre e lazer. Descanso para o trabalhador, tempo livre para práticas do ócio criativo e lazer para fruição de determinado bem cultural ou momento específico.

Cabe chamar atenção acerca da realidade dos bairros de periferia em geral, assim como os aspectos populares no cotidiano destes moradores, que quase sempre eram ignorados por estudos urbanos. Assim, José Magnani (1986) em "Festa no pedaço: cultura popular e lazer na cidade”, verificou uma ampla gama de sociabilidades produzidas e criadas, para além das marcas da exploração da mão de obra urbana, mercado informal e operários, descaracterizando a ideia de indivíduos programados apenas para o trabalho e incapacitados para o prazer. Assim, situa o autor, ao afirmar que esses temas culturais raramente eram investidos como mote pesquisa das ciências sociais pois haviam problemas teóricos da disciplina, ocasionando sempre em limitações de análise de categorias impostas pela relação periferia-pobreza, feita entre o gosto popular pelo futebol da várzea, e a partir de melodramas históricos pela televisão na produção de uma 'alienação'.

Por outro lado, é a partir da relevância destes estudos baseados nessa relação dual, iniciados por Magnani, do qual buscou estabelecer um outro ponto de análise e ampliação da categoria, para além desse dualismo baseado na insistência de observação pelo social, entendendo ser possível uma outra interpretação das diferentes classes sociais e seus estilos de vida - levando em conta seus fatores culturais, tal qual indicou Velho sobre o conceito de sociedades complexas ao longo de seus trabalhos. E dentro deste mote de estudo nos aproveitamos da dimensão das sociedades complexas propostas por Velho, que adentra novamente no nosso universo de observação, pois, conforme Magnani (2003:29):

Frente ao universo do trabalho, já subjulgado pela lógica do capital que tenta programá-lo inteiramente, existe um espaço regido em parte por outra lógica, e aberto ao exercício de uma certa criatividade: a vida familiar, o bairro, as diferentes formas de entretenimento e cultura popular que preenchem o tempo do lazer.

Assim, diante das estruturas sociais produzidas por estes arranjos urbanos, de dominação ideológica, conflito político, de desiquilíbrio econômico, não podemos reduzir

constante nas senzalas, nos locais de trabalho, nas cidades e fazendas, em locais de encontro e festas, no Brasil ou nos Estados Unidos, mas também ultrapassou o mundo dos escravos e de suas festas. 
o social simplesmente a estas práticas, que são importantes, mas que não formam completamente o sujeito. $\mathrm{O}$ que nos condiciona a abordar os aspectos culturais destas determinadas estruturas. Um dos aspectos entendidos dentro do contexto da pesquisa por meio dos relatos de Jonas, foi a musicalidade negra contida como parte integrante da sociabilidade de determinados momentos, que faz parte deste universo simbólico pesquisado, omitido muitas vezes em diversas pesquisas sobre a história local da cidade. Muitas vezes há um desprezo por estas práticas contidas em discursos de ódio e racismo, produzindo violências étnicas.

Atrelando tais práticas a partir das quais buscamos retomar a narrativa de Jonas e de uma comunidade negra portuária, que conforma sociabilidades musicais, em relação ao ambiente e sua percepção destes momentos produtores da música e do lazer, que dialogavam com a cidade no geral e, em específico, com alguns bairros e pontos de Pelotas antigamente. Em uma das passagens de sua narrativa, reflete sobre a forma de comunicação de cena musical, do batuque e da bateria com alguns outros pontos de Pelotas:

\begin{abstract}
A bateria (cozinha) não está rolando. A comunidade se envolvia com música. Ouvia de perto, ouvia de longe, sabia o que tava acontecendo. Esses caras sabiam ouvir tambor. Eles estavam na várzea, e ouviam o que eles estavam batendo lá no Areal. Comunicação com o tambor. Exemplo: O invasor está chegando. Uma comunicação musical pelo tambor, eles ouviam lá na Princesa Isabel. Tu tiravas um toque aqui, eles tiravam um toque lá. Era uma espécie de provocação dos tambores entre os bairros. Com o tempo e com a perda destes costumes de fazer música aconteceram o desaparecimento do tambor, da madeira; e do tipo de tronco. Vários tipos de tambores desapareceram. (Jonas Santos, 2018).
\end{abstract}

Pensando nesse processo de constituição temporal de uma outra ambientação urbana que Jonas conta, ele mesmo situa a relação de seu passado vivido com seu presente. $\mathrm{O}$ que nos fornece pistas para pensar na sua experiência vivida ao trilhar seus caminhos na vertente musical que se atualiza nesse entrecruzamento na sua formação enquanto sujeito citadino. Promove-se um deslocamento da noção do Porto, isto é, do bairro em si, mas sim como uma região - de locomoção e de movimento. Entre a sua percepção de vivência de bairro e de cidade.

O samba e o baile - Tambor presente no samba. Códigos de cumprimento na época. Sobre o Jovem no baile Black, se tinha mais negros, e samba e tinha esse ' $Q$ ' de mais democrático, tinha os malandros, caras das diretorias das escolas de samba, a coisa era mais misturada. Muita gente branca nas escolas de samba. O baile Black é a música que nós queremos ouvir. Os brancos estão 
ouvindo música pop. Tínhamos essa opção da música preta, da música negra. Competição com os caras do Pestano. Com o pessoal de Rio Grande. É um processo cultural que começa nos EUA, e que desencadeia na explosão cultural vindo pro Brasil - Jazz, New Orleans - ritmos jazz, blues. Samba também tem origens africanas - Sambé, e está no terreiro. A manifestação cultural que é o terreiro, por causa do seu Axé, está ligado à nossa energia. Samba é muito forte, é um ritmo muito forte no Brasil. O samba se reinventa. Cartola, Pixinguinha, o teu vô (André). Pegada soul, Amy Winehouse. Os Jazzes mais contemporâneos, Mile Davis, faltaram... e hoje em dia ninguém resgata. O samba é outra coisa, está na veia do povão brasileiro. O samba tá no maracatu, no bumba meu boi. Tá na percurssão. Acho que até James Brown era brasileiro [pausa para um ritmo falado pelo entrevistador]. Percussão vocal na música vocal. O que é que é isso aqui? É um baixo - Não, é um tambor, é uma bateria, é uma percussão. A maneira como o cara enxerga as coisas. Isso nasce nos Rituais de batuque, de percussão. Na minha opinião o samba se reinventa, se destaca. A música tomou um folego, com as festas pelo mercado [público de Pelotas]. (Jonas Santos, 2018).

Esta narrativa que Jonas aponta em sua experiência de morador do Porto, faz com que se possa pensar nas relações da diáspora da cultura africana no mundo, com a tradição da música negra de Pelotas. Isso só é possível por intermédio dos fluxos que o deslocamento planetário (entre continentes e cidades) permite estabelecer com as relações de trocas, na criação de um repertório cultural sonoro e musical.

A partir da dimensão etno-musical e da antropologia sonora, é possível situarmos este relato como produto da "caracterização dos diversos arranjos de exercícios de diálogo com vestígios de sonoridades africanas" (Da Silva, 2002). Assim, busca-se refletir sobre a linguagem musical como um objeto de símbolos no processo histórico, aprendida no seu deslocamento pelo Atlântico. Darmos atenção a este dado etnosonoro é também, de certa forma, "refletir sobre as relações etno-raciais, tematizando a cultura musical, como um espaço de congraçamento social, construção e preservação renovada em laços identitários (Da Silva, 2002: 456).

Assim, a região portuária constituída primeiro com status de Zona de Várzea ${ }^{26}$, tendo a sua maior parte de operários das fábricas e indústrias locais, acabou gerando

\footnotetext{
${ }^{26}$ Retiramos um trecho de Essinger (2012: 13) no qual descreve a Várzea tendo na topografia da cidade a sua justificativa. Conforme Mario Rosa (1985:61), a área urbana de Pelotas está localizada em um terreno que apresenta terraços, que são áreas mais elevadas onde se situa o centro da cidade, e várzeas, superfícies mais baixas "planas e constituídas de aluviões mal drenados". Por outro lado, a autora, situa num contexto sociológico, que esta denominação esteja ligada ao que Roberto DaMatta (1997: 30-31) chama de "lógica social", nomeando-se os espaços conforme sua segmentação social ou econômica. Assim, o nome Várzea pode indicar um duplo sentido: local baixo, úmido e alagadiço; local onde se instalou a população de camadas mais abastadas. Como descreveu Essinger com seus interlocutores em sua pesquisa sobre a Fiação de Tecidos no Porto e por meio das narrativas de Jonas em minha pesquisa, aponto na mesma direção, que a população se apropriou da denominação da área para indicar seu local de vida. É possível, assim, dizer que este espaço tomado em seu tempo se configura como um lugar de memória na interpretação do conceito de Pierre Nora (1993), pois é permeado de simbologia para diversos grupos de pessoas de grupos heterogêneos do passado com um passado em comum.
} 
subsistemas de vida, com base nas relações do trabalho, seja nas fábricas, como operários, ou na rua, com os sub-trabalhos, espalhados diretamente pelo Porto com os estivadores e cabungueiros, até as menos diretas como as dos músicos, percorrendo até o centro como engraxates. Essa cartografia do trabalho portuário, podemos dizer, mapeava a posição social dos sujeitos diante da cidade. Destas relações citadas, muitas delas, foram tecidas sob outras redes de referenciamento do bairro, que ambientaram diferentes classes sociais e costumes diversos, como apontamos, produzindo outras escalas de vizinhanças.

Compartilhando espaços de conflitos e busca por reconhecimento identitário, por meio de itinerários urbanos das sociabilidades estabelecidas, o espaço que é permeado por relações de solidariedade na ajuda mútua do dia a dia, com o partilhamento dos cuidados dos filhos, por meio da tutela coletiva, além das sociabilidades evidenciadas com os Clubes Sociais Negro. Também territorializou-se neste espaço a eventividade burlesca diante de determinadas ações culturais, como a criação de blocos carnavalescos que, posteriormente, chegaram a ser agremiações, sendo atualmente o espaço no qual ocorre o carnaval Pelotense. Além dos clássicos campeonatos de futebol amador da várzea, até rituais religiosos como a festa de Nossa Senhora dos Navegantes ou Festa de Iemanjá, como reforça Jonas, aos quais a comunidade portuária comparecia em grande público.

Neste mesmo espaço também era partilhado a simples convivência cotidiana, do dia a dia, da conversa nas calçadas, dos festejos dos aniversários, das caminhadas em conjunto até o local do trabalho, como bem relata Jonas. A partir desse compartilhamento de espaços e lugares no âmbito da rua, foram-se criando certos hábitos pelos moradores. Um deles, que permanece em sua duração, como observado inúmeras vezes pelos pesquisadores, é o de estar sentado na frente de casa, principalmente no verão, como uma forma de sociação aos acontecimentos da ordem do dia, na forma de um certo controle sob o lugar, por meio das ditas 'fofocas', ou até mesmo pelo simples momento ordinário de estar na rua, entendido como uma extensão da casa, principalmente situados em um formato ‘comunitário' e familiarizado de habitação coletiva.

Interessante trazer este último relato para observar como ele se mantém ativo, sendo perceptível como a cultura das sociabilidades na calçada de casa ajuda e ajudou na formação das vizinhanças, criando laços, alianças e proximidades. "A maneira como o cara enxerga as coisas", diz Jonas. Esse ponto é crucial para compreendermos como ele 
enxerga a sua cidade, tomada por um conhecimento que parte de sua vivência e experiência no Porto, assim como transborda para outras regiões da cidade.

Atualmente, Jonas Santos, artista, trabalha com artes visuais, em especial atenção na criação com Revistas em Quadrinhos. Por meio da utilização da linguagem artística, Jonas é considerado um narrador das tramas urbanas, que narra suas experiências no bairro por meio de sua produção artística visual desconstruindo e recriando a sua Pelotas, a partir do gênero da ficção com traços de realidade de suas vivências e experiências. Além desses aspectos empíricos, endossamos pelo conteúdo artístico, traços memoriais compartilhados em coletivo, transmitidos por seus familiares e antepassados, na forma de mitos e lendas situados numa cosmovisão étnica, ajudam a configurar o bairro do Porto e mesmo a cidade de Pelotas de Jonas.

\section{Formação da comunidade universitária no bairro do Porto}

A partir da expansão da Universidade Federal de Pelotas (UFPel), iniciou-se um importante processo de revitalização dos polos fabris abandonados, visto que, ano de 1996, negociou-se com a empresa COSULÃ e o Banco Brasil (credor da empresa) a aquisição dos antigos prédios utilizados pela cooperativa para sua revitalização e utilização como unidades acadêmicas. Todos os prédios adquiridos foram profundamente modificados para atender às necessidades acadêmicas.

Figura 22 - Antigo Frigorífico Anglo.

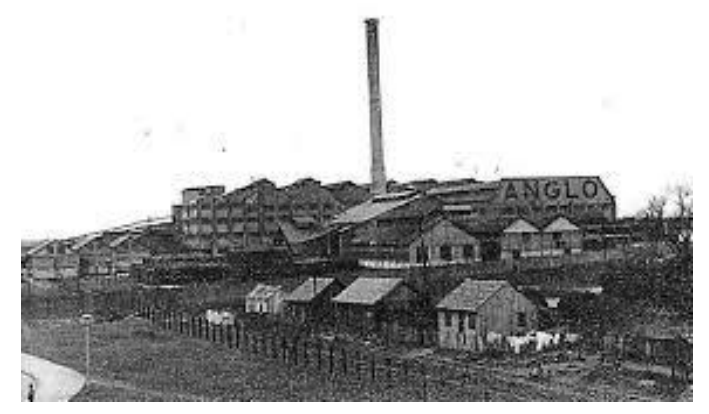

Fonte: Acervo dos autores 
Figura 23 - Atual prédio da UFPel, Anglo, 2018.

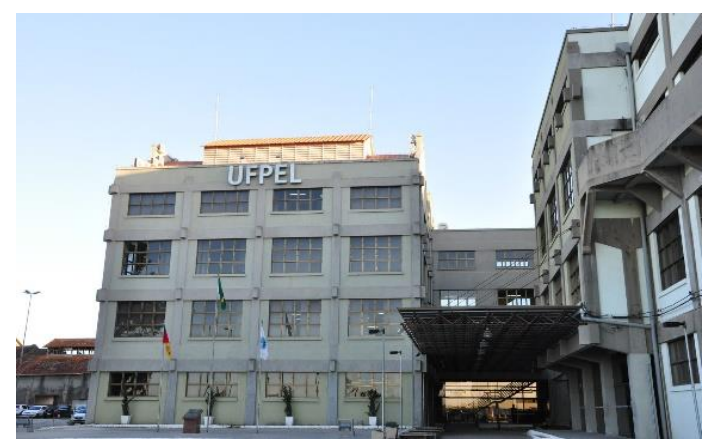

Fonte: Acervo dos autores.

Atualmente, nos prédios da antiga COSULÃ, estão instalados cinco Unidades Acadêmicas, o ICH (Instituto de Ciências Humanas), IFISP (Instituto de Filosofia, Sociologia e Política e a FAE (Faculdade de Educação), a FAUrb (Faculdade de Arquitetura e Urbanismo), e o IAD (Instituto de Instituto de Artes e Design). Neste mesmo propósito, a universidade comprou em conjunto com a fundação Simon Bolívar, a área ocupada pelo antigo frigorífico Anglo, onde está construído o campus Anglo.

Figura 24 - Campus ICH antigo Cosulã, 2018.

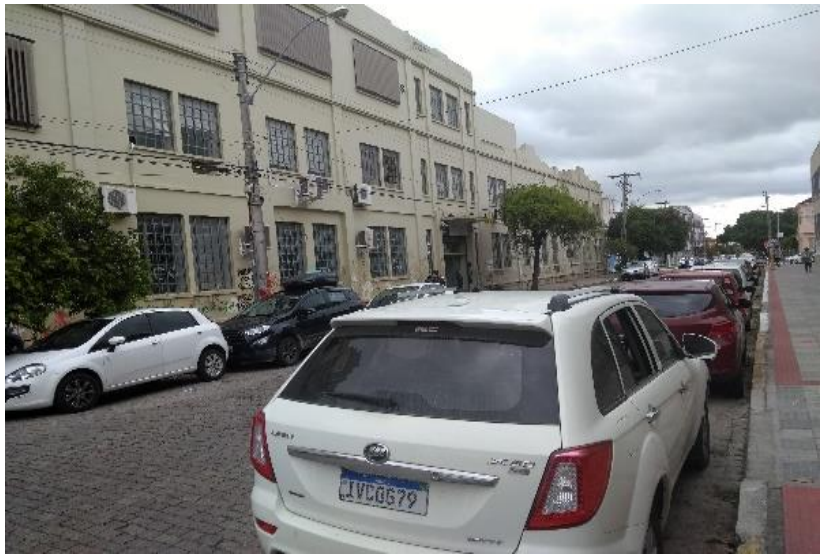

Fonte: Acervo dos autores

Notou-se a presença de muitos cursos da Universidade Federal de Pelotas que estavam adquirindo inúmeros prédios na zona central da cidade, mas também na região portuária, dinamizando consideravelmente o bairro.

Com isso há o estímulo de um grande número de investimentos imobiliários destinados aos estudantes e a alterações na vida econômica do bairro. Nesse movimento de ingresso ao sistema universitário, a sociabilidade a princípio forjada na vida 
acadêmica se expande e ultrapassa o campo educacional, na formação de uma comunidade estudantil no bairro.

Por conta do bairro ter perdido sua 'função' ativa principal, a da industrialização e movimentação de mercadorias pelo Porto como vimos com Jonas, tornou-se, com o passar dos anos, um bairro desprovido da prestação de serviços públicos como falta de iluminação e sinalização, ruas esburacadas - em razão da pavimentação feita de paralelepípedos, fazendo parte do cenário do bairro de caráter secular, ocasionando a insegurança no bairro, desvalorizado e habitado por novos moradores, majoritariamente de baixa-renda. Por meio deste tipo de migração e deslocamento estudantil no bairro, ocorreram melhorias, mas ainda é visível o alto índice de imóveis para venda.

Pesquisas com a de Tauê Al-Alam (2011), buscaram situar a transformação do bairro a partir da inserção da Universidade Federal de Pelotas na região, com a política pública de educação do Programa de Reestruturação e Expansão das Universidades Federais (REUNI) que compra e restaura inúmeros prédios fabris e abandonados por este hiato temporal de decadência fabril na cidade. O bairro do Porto se reconstitui a partir de outras dinâmicas e permanências de lazer noturno que faziam parte de um público local, até a inserção da UFPel que traz consigo novos habitantes, como os estudantes e docentes que vão fazer parte destes espaços de convivência. $O$ que se percebe e mais profundamente é o crescimento de uma sociabilidade noturna e a modificação do cenário através de uma cultura juvenil de rua que ocupa e reconfigura o espaço urbano.

Em consonância com o movimento universitário inclusivo no bairro, há o surgimento de atividades artísticas e culturais que dão ritmo e informam um outro compasso temporal junto ao dos habitantes remanescentes trabalhadores do seu período fabril em sua maioria idosos. Conforme acontecem estas novas peregrinações (Velho, 2009) no formato universitário, vão se acoplando ao cenário do bairro e formulando a paisagem entre o jogo das habitações, as formas e estilos de vida na produção de uma estética geracional do Porto, que se acomoda entre pequenas casas antigas e gradeadas, prédios residenciais novos, habitados por idosos e universitários, formando e sobretudo compartilhando novas redes geracionais de vizinhança.

A nova paisagem estética urbana da região portuária pelotense recoloca novas atividades agora, sobretudo juvenis criando novas espacialidades e formatos de utilização do bairro. A nova espacialidade do bairro que foi criada, tomada em sua grande maioria por um público jovem e universitário, postos entre diversas faixas etárias, com ocupações profissionais ou não, independentes financeiramente ou não, é entendida como 
pertencente ao estilo juvenil-universitário criado no e do bairro. Assim, por meio de sua conformação e legitimação das práticas, pode ser compreendida como um território juvenil. Para tanto, por meio das narrativas juvenis que qualificam e sinalizam uma interpretação que confere centralidade ao lazer, entendido também como o tempo livre.

A partir da presença destes novos grupos visivelmente espalhados pelo bairro, tais equipamentos e espaços criados para estas práticas de lazer e tempo livre, acabaram tornando-se parte do cotidiano do lugar, conformando uma dinâmica urbana própria com base na qual foi possível mapear alguns pontos característicos que entendemos como um circuito territorial que faze parte das dinâmicas juvenis do bairro do Porto.

Com a observação etnográfica foi possível mapear o que chamamos de circuito juvenis-universitários no bairro que desenham certas práticas diurnas e noturnas além do cotidiano universitário criado com o polo educacional. Assim, efetiva-se um espaço urbano tanto para práticas mais particulares dos grupos por meio das manchas ${ }^{27}$, quanto conformam um circuito mais diversificado fazendo surgir diversos equipamentos culturais noturnos em estabelecimentos, como o Bar do Zé, Papuera Bar, o Galpão do Rock, Galpão Satolep, até o último e mais recente no Porto como o evento artístico Sofá na Rua. Cada um destes equipamentos citados está inserido em um circuito noturno do bairro por meio de práticas semelhantes como as sociabilidades coletivas do qual situaremos a seguir.

Bar do Zé. Com a chegada da Universidade no bairro, tornou-se um ponto de encontro para o público universitário das 'humanas, sociais e das artes', ou seja, os estudantes que passaram a frequentar o entorno do bar com funcionamento principalmente à noite.

Figura 7 - Dia de encontro no Bar do Zé, 2019.

\footnotetext{
${ }^{27}$ Para mais detalhes sobre o conceito, ver Magnani (2008).
} 


\section{Ícaro Vasques Inchauspe e Francisco Luiz Pereira da Silva Neto}

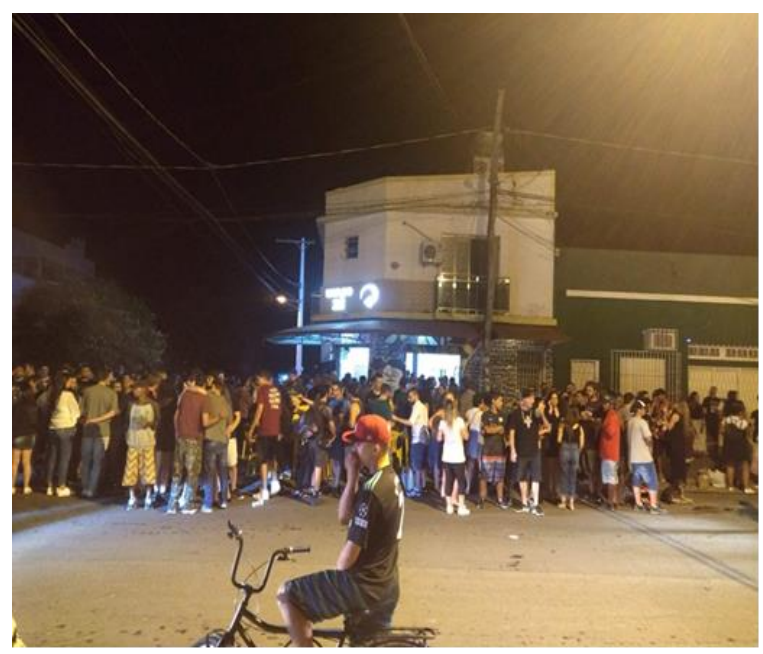

Fonte: Acervo dos autores

Figura 8 - Frequentadores no Bar do Zé ao lado do Centro de Música da UFPel. 2019.

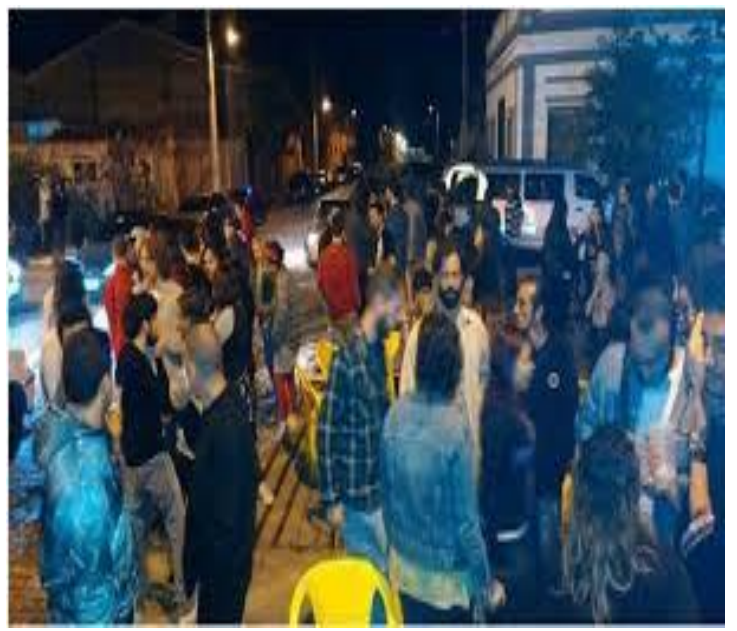

Fonte: Acervo dos autores.

Em meados de 1950, funcionava como um armazém para frequentadores e moradores da área agroindustrial, conforme situamos nos capítulos anteriores. Mesmo assim, o local resguarda uma característica importante, pois, além do público jovem, atraía os demais públicos, ou seja, os moradores mais antigos. Por isso, se tornou um ponto de encontro para alguns grupos como a galera do rap, hip-hop e do grafite que ali faziam o 'barulho' e suas movimentações artísticas no anonimato, segundo guia a ética destes atores.

Neste mesmo ambiente também foi possível observar um evento em especifico: o início da realização dos trajetos dos 'rolês' entre pixadores e grafiteiros. Nesse rolê particular, a 'missão' era realizada entre uma série de grupos, como os 'manos' e pixadores do HP (Hip-Hop) alguns advindos do bairro Dunas, periferia de Pelotas. De 
modo semelhante, também podem ser encontrados pixadores identificados com siglas do bairro Fragata, que são identificados pelo fardamento utilizado, como membros das torcidas organizadas de futebol como a do Esporte Clube Pelotas (E.C.P) - Força Jovem de Pelotas (FJP).

Além disso, o estabelecimento atrai músicos mais antigos e segmentos musicais como sambas da velha guarda da cidade, além de outros gêneros como o pop rock. $\mathrm{Na}$ perspectiva do ethos de Geertz (1989), acaba produzindo valores e performances de uma 'geração de gerações' provendo continuidades cotidianas do bairro em relação a certas sociabilidades. Criando subsistemas de vida, como a formação de setores do subemprego informal, entre músicos e universitários, que acabam se tornando universitários-músicos, entre frequentadores, usuários e artistas durante a semana.

Galpãp Satolep. Galpão do Rock, criado no ano de 2003, pelo produtor cultural Manoval Robe, que tinha como um dos objetivos criar um espaço 'underground' para a galera do rock and roll. Para realização do reduto, era necessário criar um ambiente propício e, de acordo com o termo expressado "underground", somente seria possível com o cenário adequado.

Figura 9 - Fachada do Galpão, 2019.

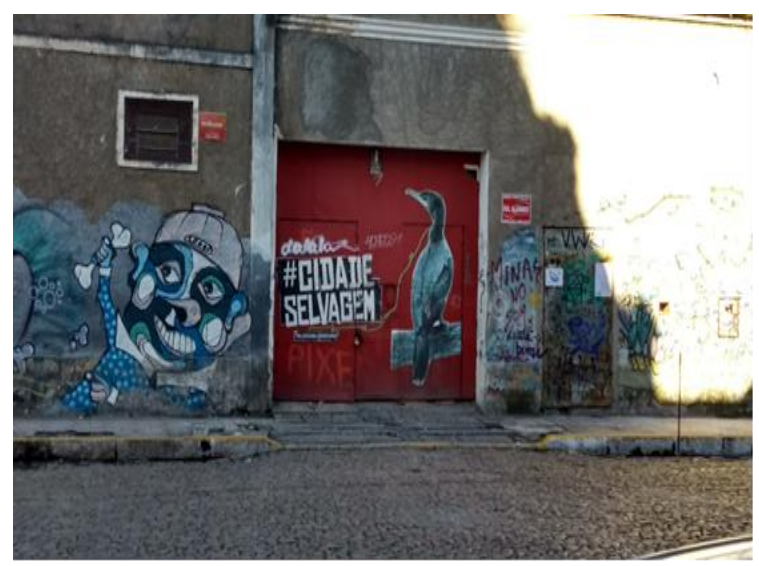

Fonte: Acervo dos autores

Figura 10 - Apresentação Musical da Banda Acústicos e Valvulados. 


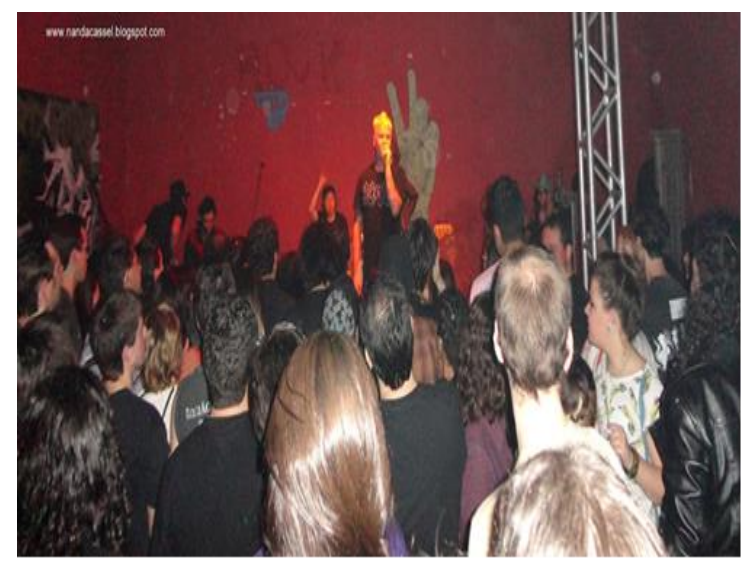

Fonte: Nanda Cassel.

O cenário foi a região portuária de Pelotas, com o seu complexo fabril degradado pela desistência de uma série de atividades não mais rentáveis no setor, que tiveram as atividades centralizadas em outras partes do estado e do país, além do abandono da infraestrutura do bairro, sob tutela do agente público local.

O 'Galpão Satolep' ou mais conhecido como 'Galpão do Rock' teve seu auge nos anos 1990 e 2008 especificamente no recorte do gênero do rock, metal, heavy metal, hardcore e afins trazendo bandas do cenário nacional como Raimundos, Ratos de Porão, Dead Fish e bandas locais undergrounds, além de bandas covers com prestígio na cena musical do rock.

Desta forma, estes elementos produzidos pelo bairro são norteadores para designar um ambiente cultural, que 'foge' dos padrões comerciais e de modismos que estão fora do centro ou da mídia.

André: 'Tchê'... Eu morei aqui no Porto, de 2004 a 2008 antes de ir pra praia [bairro do Laranjal - Zona Norte] com a minha mãe, e cara... era muito metal, rock, hardcore, punk que rolava no Galpão... aquela coisa bem trash. Bom tu vê, pela aparência do 'negócio'. 50 metros quadrado $\left(\mathrm{m}^{2}\right)$ tudo rebocado com cimento. Bem aquele tipo de lugar só para estocar produto... Galpão... o nome já diz tudo... Um depósito... então é isso, um lugar trash merecia bandas trashs... depósito da nossa loucura. Hoje em dia, eu quase não frequento mais.. tô mais velho né. Tenho mais responsabilidade. E tem outra coisa né... com a instalação da Universidade, aí, diversificou o perfil. Tem festa de rap, funk.. São as gerações cara...(Relato de André Gomes, 25 de maio de 2018).

Jonas Fernandes: Eu morei minha infância aqui, na década de 1970 até 1995 , tinha toda uma 'função' da cultura negra e operária aqui no Porto, a sociabilidade produzida aqui era muito mais voltada para os Clubes Negros, para os cordões de carnaval. Tinha toda aquela coisa ligada ao trabalho do estivador, descarregador de mercadoria e área pesqueira. O samba e a musicalidade nossa era toda criada aqui nessa região portuária que ia desembocar lá no centro da cidade, e na criação da música dos Clubes Negros mais dessa região. Hoje em dia, mesmo com os moradores antigos que trabalharam no Anglo e na Brahma, esse último aí, já mais velhos, a rotina do 
Porto mudou com toda dinâmica universitária. É outra pegada. (Relato de Jonas Fernandes, 13 de agosto de 2018).

Por meio da diversificação do público local com a instalação da UFPel no bairro e, consequentemente, com a chegada dos moradores universitários, o nome mudou para Galpão Satolep ${ }^{28}$. Decodificado o termo necessário para um primeiro acesso das práticas do local, ocorre uma dinâmica própria de convivência, regras e ordenamento entre grupos desde os mais 'undergrounds' como alguns remanescentes do trashmetal, punk, grupos femininos de góticas, até os atuais, muito solicitados como o funk, música pop, entre outros. O Bar do Zé para alguns grupos serve como um ‘esquenta' para o Galpão.

Atualmente, o equipamento é frequentado mais assiduamente pelo grupo universitário-juvenil que reside no bairro, mas também tem como público os demais grupos universitários espalhados pela cidade.

Sofá na Rua. "Para sair do eixo? Pega e bota o Sofá na Rua", disse Marcelo Rota, um dos primeiros frequentadores do Sofá. Assim nasce o Sofá na Rua em Pelotas. Embrionada pelo coletivo cultural Fora do Eixo (FdE) $)^{29}$ de abrangência nacional, tendo sua criação em Goiás e se espalhando rapidamente para diversas cidades do Brasil. Desde 2012, em Pelotas, iniciaram suas atividades morando em casas de cinco a seis pessoas, trabalhando no formato coletivo com o ideal de prover atividades artísticas na cidade.

Figura 29 - Sketch da edição do Sofá na Rua em comemoração ao Dia das crianças, 2019.

\footnotetext{
28 "A prosódia de Pelotas ficava ruim para cantar. Foi aí, que um amigo sugeriu porque costumávamos falar palavras ao contrário", explica. Além de criar esse termo, em suas apresentações, Ramil apresentava-se como o Barão de Satolep, um nobre pelotense, pálido e corcunda, alter-ego do artista, figura ao mesmo tempo divertida e mal-humorada. Satolep quer dizer Pelotas ao contrário, ou como um anagrama, que lido da direita para a esquerda forma o nome da cidade de "Pelotas", como indica o criador da alcunha, Vitor Ramil no livro Satolep.

${ }_{29}$ Para uma melhor leitura e compreensão profunda sobre a história do coletivo, ver Savazzoni (2013; 2014) e Irisarri (2015).
} 


\section{Ícaro Vasques Inchauspe e Francisco Luiz Pereira da Silva Neto}

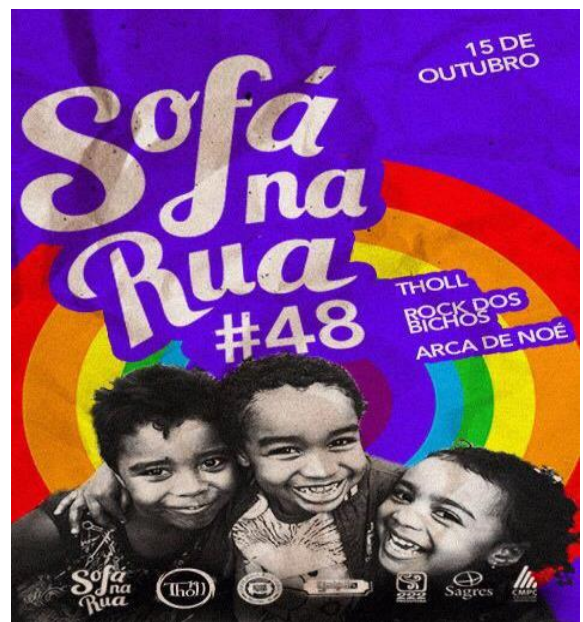

Fonte: Acervo dos autores.

Assim, surge a primeira edição do Sofá na Rua, ainda na sede do coletivo, na Rua Almirante Tamandaré. Sempre com preocupação de prover a independência do setor artístico (por isso, fora do eixo monopolizador das atividades artísticas-cultural Rio de Janeiro/São Paulo) encontra um sistema alternativo anti-mercadológico de ocupar o espaço público, a rua e, principalmente, produzir um ambiente que agregue pessoas e grupos. Ao mesmo tempo, busca fomentar esse novo tipo de sociabilidade, até então inexistente neste formato, na planificação do cultivo de uma nova cultura urbana pelotense.

Figura 30 - Famílias no primeiro plano.Sofazinho no segundo plano e Basquete 3x3 no terceiro plano, 2019.

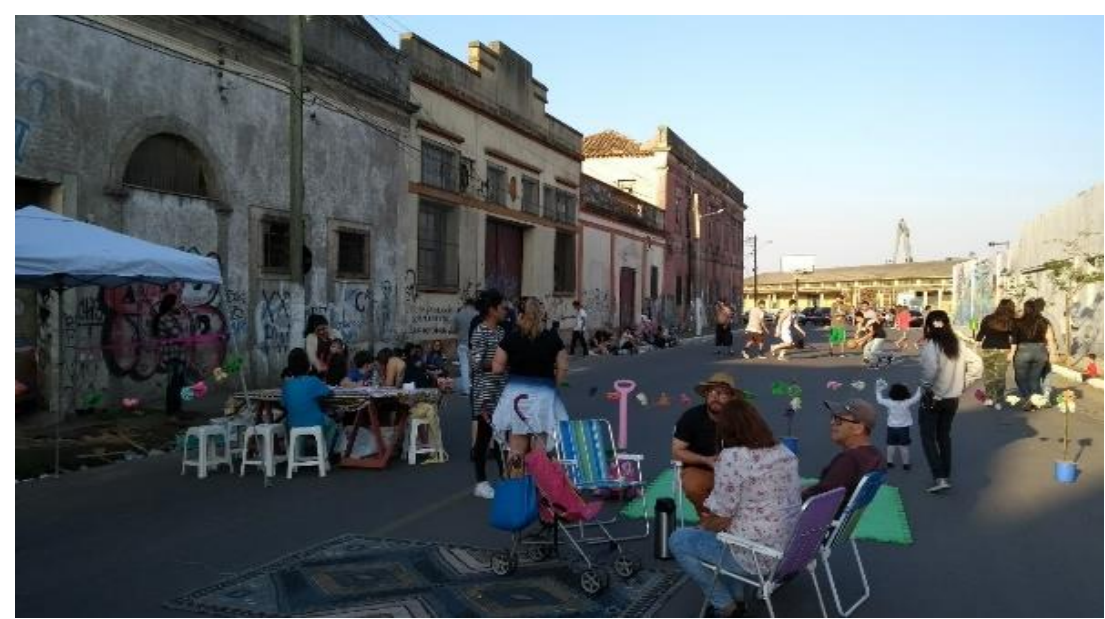

Fonte: Acervo dos autores

Em 2014, já desvinculado ao FdE, o evento é remodelado a partir de aprovação do projeto submetido no Programa de Incentivo à Cultura (Procultura), da Prefeitura 
Municipal de Pelotas, tendo seu lançamento já na rua José do Patrocínio, na região do Porto. Ao total daquele ano, foram realizadas dezoito edições. Surge assim mais uma mancha de lazer inserida no contexto juvenil-universitário na perspectiva da cidade democrática.

Figura 31 - Sociabilidades no Sofá na Rua, 2019.

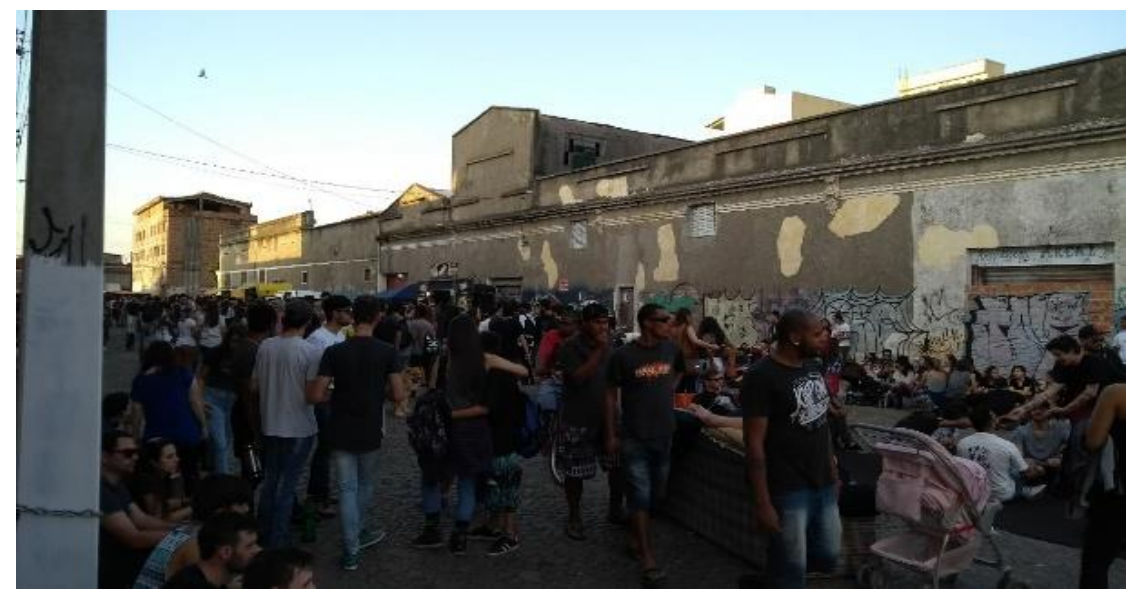

Fonte: Acervo dos autores.

A organização do evento Sofá na Rua buscou trazer o que chama de "ambiente de paz" com o objetivo de conscientizar a respeito do espaço público. Para dar movimento ao evento, atrelam as seguintes redes temáticas: economia criativa que envolvem o setor de alimentação, com os o food trucks, carroças de pipoca, doces e bebidas artesanais, até o espaço compartilhado na calçada para expositores de diferentes produtos, livros, bijuterias artesanais e, ultimamente, com o forte incentivo à moda, com os brechós.

No setor do audiovisual, há o Cine Clube, onde realizam mostras e apresentação de filmes independentes. No âmbito do lúdico, há o espaço kids 'Sofazinho' composto por atividades artísticas para os 'pequenos' (crianças de 1 a 6 anos) que desenvolve atividades lúdicas como pintura, desenhos, montagem de quebra-cabeças e outras brincadeiras. Intercalando processos pedagógicos no urbano, entre ludicidade e conhecimento, "a verdade é que os processos educativos autônomos se dão informalmente há muito tempo, nas brincadeiras de rua, no esporte de várzea" (Feixa, 2016).

Figura 32 - Desenhos realizados pelas crianças, 2019. 


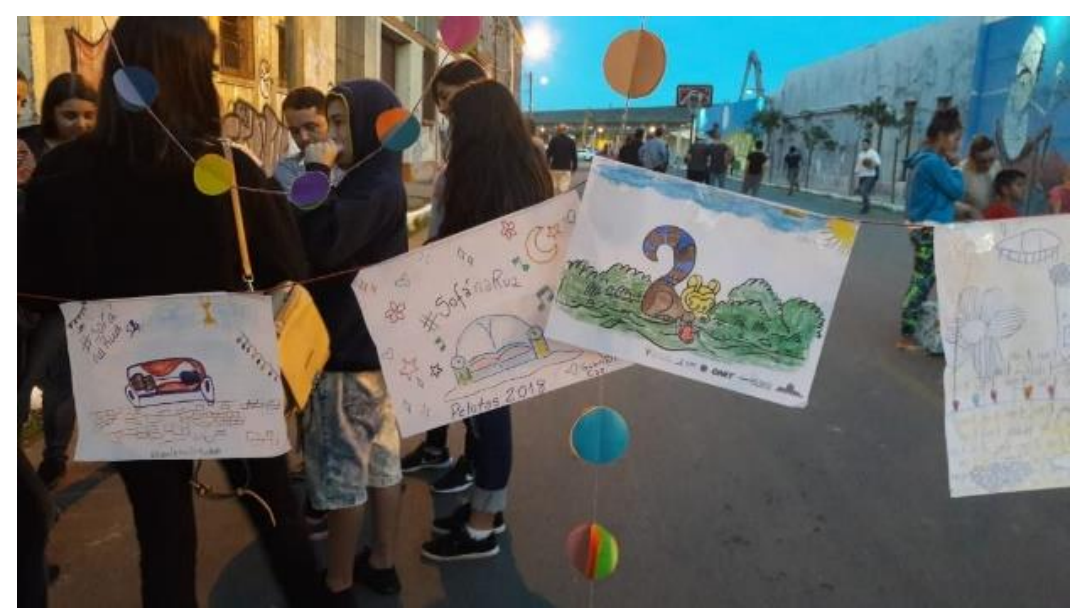

Fonte: Acervo dos autores.

Como observado, o Sofá na Rua vem na articulação em rede com diferentes coletivos, criando espaços de autonomia e produzindo vínculos entre os usuários, e potenciais fruidores e consumidores. O sentido de autonomia pelas culturas juvenis vem carregado de afetos e diversas motivações que aprofundam o sentimento de se tornarem protagonistas daquele espaço.

É o caso de Júlio, de 16 anos, paraplégico. Em um dos dias que estava no evento, pude observá-lo vendendo doces artesanais (brigadeiros de morango) em sua cadeira de rodas, com seus familiares em torno no auxílio. Ao comprar um doce e iniciar uma breve conversa, perguntei o que ele achava do evento. Prontamente ele me disse que ali: "ao invés de ele ser olhado diferente por andar numa cadeira de rodas", ele era olhado "por ser diferente entre os diferentes", o que o tornava próximo. Além desse sentimento de liberdade, o espaço oportunizava uma atividade econômica que rendia uma "boa grana" para, inclusive, custear uma parte de sua fisioterapia. Disse gostar também em razão da recepção calorosa com que sempre era recebido quando participava. O fato de ser uma rua de difícil acesso, ou praticamente não haver acessibilidade naquele equipamento urbano, era importante, mas não fazia muita diferença naquele momento.

Outro fator interessante que baliza a definição destas práticas no Sofá, pode ser interpretado pelo aspecto geracional presente no evento Sofá na Rua, que acaba agenciando as sociabilidades temporais, entre moradores mais antigos e os novos moradores, bem como transeuntes do evento. Especificamente neste evento, a nitidez corporal de ocupação do espaço é mais presente. Assim, como no Bar do Zé, a ocupação do espaço da rua é literalmente performática, expressa na forma como os frequentadores sentam nas cadeiras de plástico do bar e, principalmente, sentam no meio da rua, no meio 
fio das calçadas. São atos que produzem um sentido de relaxamento e descompromisso de valores e normas de postura, que outros espaços mais 'requintados' possam sugerir e, tecnicamente, obrigá-los a este tipo de controle.

Abaixo na imagem está Seu Osvaldo, com seus 85 anos, frequentador sempre que possível do Sofá. Diversos casais de uma faixa etária maior também frequentam, tanto do bairro quanto de outras partes da cidade.

Figura 33 - Geração de Sociabilidades.Seu Osvaldo e jovens

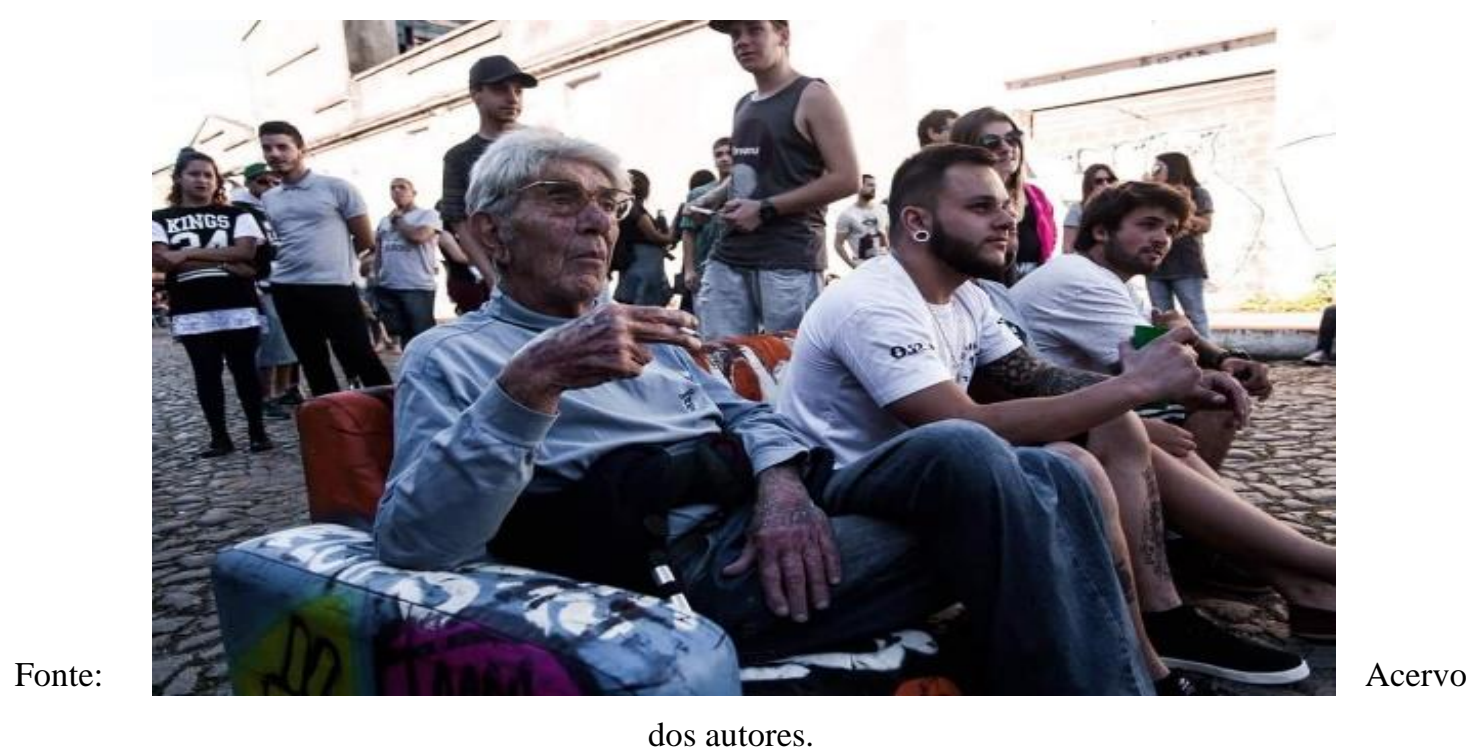

Até o final de dezembro de 2018, foram realizadas 60 edições do Sofá na Rua. Por meio do trabalho de campo realizado na região que conforma o bairro, observando o mapeamento deste circuito juvenil-universitário, pude acompanhar desde a $47^{\mathrm{a}}$ edição até $59^{\mathrm{a} 30}$, totalizando 11 participações, de julho de 2017 até dezembro de 2018 efetivadas no bairro do Porto.

\section{Considerações finais}

\footnotetext{
${ }^{30}$ De acordo com a matéria publicada no Jornal E-cult de Pelotas sobre o Sofá na Rua; ao longo destes 7 anos de atuação, traz alguns dados interessantes que marcam a sua presença com 163 bandas circuladas, 15 brechós parceiros; 12 redes de foodtrucks; 21 exibições de filmes; 36 apresentações cênicas; aproximando um público de 72 mil pessoas; realizando 195 hospedagens de artistas, produtores e mídia livristas da América Latina; 40 oficinas.

Retirado de e-cult: http://ecult.com.br/artes/sofa-na-rua-chega-a-sua-60a-edicao-empelotas?fbclid=IwAR2yfB-YOfXJThnNNgrQYtMQJtylDYRw8V1Uyw2RRcApXeUEzJBhE_HO9U8.
} 
Ao longo que se seguiu este trabalho, propomos caracterizar duas passagens que nos fornecem pistas para interpretarmos a temporalidade do bairro do Porto. A primeira, marcada por meio dos estudos da memória e da rememoração, com Jonas Santos que, na figura do narrador urbano, relata um Porto baseado em suas vivências de ex-morador, permeadas por atividades fabris e agroindustriais.

Sua subjetividade está alicerçada pela herança cultural transmitida por meio da difusão étnica da cultura negra africana-brasileira e pelotense, que também conforma um bairro negro no sentido de estabelecer uma narrativa coletiva em busca da defesa de uma identidade portuária negra.

No seu jogo de memórias, entre o que vivenciou individualmente e o que lhe foi aprendido por seu núcleo familiar, coletivamente, nos mostra um bairro negro, às margens do exercício citadino, especificamente nas questões do direito à cidade e da "cidadania de seu grupo", como relata Jonas. Ou seja, a pertença de inserir-se nas práticas e no exercício ativo tanto das escolhas quanto de decisões, tanto da cidade, quanto especificamente no bairro de forma geral, dos direitos sociais que lhes eram (e são) silenciados e vedados.

Como apresenta sua narrativa, há uma incorporação de outras narrativas que, em certos momentos, não lhe foram presenciadas e nem vividas, mas transmitidas pela ampla comunidade da qual se sente pertencente. Nesse sentido, ao mesmo tempo são incorporadas em sua narração. Podemos apontá-lo como um herdeiro urbano, a partir da transmissão de um patrimônio étnico reminiscente e imanente, no reforço constante de busca por um espaço, além de evidenciar as estruturas urbanas narradas que conformam uma temporalidade (passada, presente e negociada em busca de um futuro próximo) sempre na permanente dialética, entre sua "afirmação de identidade (perpetuação) quanto a da ipseidade (manutenção de si)" (Rocha; Eckert, 2011: 110).

A identidade do interlocutor e ex-morador observado pode ser compreendida no interior de um acontecimento narrativo, que tem na sua própria trama o esforço de enquadrar seus percursos ou trajetos espaciais, simbólicos no bairro, como operador de deslocamentos, que produz e forja um certo tipo de memória das práticas na cidade. $\mathrm{Na}$ busca coletiva pelo alargamento de determinadas práticas, sociabilidades e itinerários urbanos percorridos pelo bairro a partir dos quais produzem o seu habitar.

Dessa forma, empregamos nos estudos da memória o exercício da etnografia da duração mostrando a durabilidade destas narrativas que consolidam, ao longo de seu tempo, uma prática citadina que nos conduz a perceber além da sua durabilidade, a 
capacidade de negociação e forjamento do tempo por meio das práticas cotidianas, na busca da defesa dos diferentes ritmos pelos quais o bairro passou e vem passando.

Em conexão com esta durabilidade narrada no bairro, tratamos como análise pontual o fato da complexidade das relações que são produzidas na transformação temporal citadina do lugar. Assim, realizamos na segunda passagem temporal do bairro observado, diante da pesquisa etnográfica sobre um "tempo presente", presenciado e observado a partir das modificações que vem sofrendo com a chegada de diferentes grupos sociais que estão se estabelecendo na região portuária.

Com base em uma expressiva camada juvenil-universitária, reconfigura arranjos espaciais, antes tomados especificamente ao labor - trabalho fabril e industrial, as fábricas, galpões e estabelecimentos comerciais -, agora são tratados na forma de equipamentos noturnos do bairro e da cidade a partir da busca pelo lazer e da festa, por meio de agrupamentos em busca de outras rotas para o tempo livre e produção de sociabilidades, afetos ou encontros no bairro.

Como mencionamos na introdução deste trabalho, os encontros temporais em sua conjunção dialética trazem categorias que a cidade e o bairro aqui apresentados se conformam pelo tempo e por suas práticas, materiais e imateriais. Tais categorias se alocam nas sobreposições do tempo: a) entre o antigo e o moderno, entre a fábrica e a universidade; b) conhecido e o novo, moradores nativos e outsiders, este último no sentido de determinadas práticas e hábitos alternativos de sociabilidades ao tradicional interiorano. $\mathrm{O}$ encontro geracional promovido pela dinâmica das formas de habitar o bairro produz novos arranjos, novas práticas e novos encontros antropológicos, interpostos sobre as diversas e diferentes alteridades, entre os antigos, os novos e seus próprios pares, e no próprio agenciamento sobre a cidade. Diferentes comunidades urbanas emergem diante da metaformose, originadas pela negociação entre conveniências e insurgências, inseridas num contexto situado de técnicas do cotidiano (entre o manual e o digital) entre o individual e o coletivo (redes digitais ou físicas), mas compreendido como um desejo de mudança sob o conflito de habitar no tempo presente.

Portanto, tal conjunto dialético multi-temporal de pensar o tecido urbano traz múltiplos agentes empíricos na forma de atores que acabam criando territórios variados, presenciados e narrados no bairro do Porto. Produzindo também diferentes estéticas urbanas que sobrepõem diferentes temporalidades, mas que coexistem justamente a partir do diferente, pois é especificamente a partir da diferença que a produção de um campo de novas possibilidades é concedida no acesso para formação de múltiplos arranjos. 
Por fim, cabe mencionar a importância de análise do contexto sócio-histórico de Pelotas junto ao tempo social das cidades brasileiras e suas práticas citadinas de colônia, república até o fazer-cidades democráticas. Dos deveres aos direitos, ora concebidos na construção forjada de nação de um projeto conservador ${ }^{31}$, ora na procura incessante por direitos que extrapolam estes mesmos valores normalizados ao longo do tempo, intrinsecamente habitado em grande parte da sociedade brasileira, muitas vezes em virtude da própria trajetória que persiste em continuar como sistema institucional de nação.

Em contraponto desta narrativa oficial-institucional, e em constante arranjo permeado por disputas ao longo do tempo é que surgem outras iniciativas na iminência da busca para alternativas de como habitar o cotidiano da cidade. Sendo estas etapas temporais situadas em narrativas e memorias dos agentes empíricos, interpretadas como produtos de tempos difusos que se atravessam e sobrepõem em sua duração na formação da estética urbana dos habitantes.

\section{REFERÊNCIAS}

ABREU, Martha. O legado das canções escravas nos Estados Unidos e no Brasil: diálogos musicais no pós-abolição. Revista Brasileira de História, v. 35, n. 69: 177-204, 2015.

AL-ALAM, Tauê Cardoso. De operário a universitário: transformações na paisagem do bairro Porto em Pelotas. 2011. Dissertação (Mestrado em Geografia). Universidade Federal do Rio Grande-FURG. Rio Grande, Rio Grande do Sul, 2011.

ALONSO, José Antônio Fialho. O cenário regional gaúcho nos anos 90: convergência ou mais desigualdade? Indicadores Econômicos FEE, v. 31, n. 3: 97-118, 2003.

ARNONI, Rafael. Relatos no tempo de um lugar esquecido: os Campos Neutrais do Rio Grande do Sul no registro de Saint-Hilaire. Anais [...]. V SIMP: Memória e esquecimento. 5 a 7 de outubro de 2011. Pelotas, Brasil.

AXT, Gunter. Panorama da participação da iniciativa privada nacional no setor elétrico do interior gaúcho (1889-1947): contribuições para o estudo do patrimônio industrial urbano. Revista Memória em Rede. Pelotas, v.2, n.7, jul./dez.2012.

BEAL, Sophia. Obras públicas monumentais, ficção e o regime militar no Brasil (19641985). Revista Escritos, 2010. p. 259-280.

DA ROCHA Machado, Janete. História da via férrea na zona sul de Porto Alegre. Oficina do Historiador, v. 1, n. 1: 78-91, 2010.

${ }^{31}$ Para mais detalhes ver Schawrcz (2019). 
DA ROCHA, Jefferson; BECKER, Fermiano. As raízes do declínio econômico da'Metade Sul'do Rio Grande do Sul. Redes (Santa Cruz do Sul On-line), v. 5, n. 1: 191212, 2000. Disponível em: http://cdn.fee.tche.br/jornadas/1/s12a5.pdf Acesso em: 26/09/2019.

DA SILVA, Salloma. Memórias Sonoras da Noite: vestígios de musicalidades africanas no Brasil nas iconografias do século XIX. Projeto História. Revista do Programa de Estudos Pós-Graduados de História, v. 24, 2002.

DAMATTA, Roberto. A casa e a rua. Rio de Janeiro: Rocco, 1997.

ESSINGER, Cintia. Entre a fábrica e rua: a Companhia Fiação e Tecidos Pelotense e a criação de um espaço operário - Bairro da Várzea, Pelotas, RS (1953-1974). 2009. Dissertação (Mestrado em Memória Social e Patrimônio Cultural). Universidade Federal de Pelotas. Pelotas, Rio Grande do Sul, 2009.

FEIXA, Carles. Generación Hashtag. Los movimientos juveniles en la era de la web social. Revista Latinoamericana de Ciencias Sociales, Niñez y Juventud, 14 (1): 107-120.2016.

FREYRE, Gilberto. Ordem e progresso. Rio de Janeiro: José Olympio, 1959.

GUTIERREZ, Ester. Barro e sangue: mão-de-obra, arquitetura e urbanismo em Pelotas (1777-1888). Pelotas: UFPel, 2004.

HOBSBAWM, Eric. A era do capital: 1848-1875. São Paulo: Paz e Terra, 2015.

INGOLD, Tim. Jornada ao longo de um caminho de vida-mapas, descobridor-caminho e navegação. Religião e Sociedade, v. 25, n. 1: 76-110, 2005.

IRISARRI, Victória. Fora do eixo, dentro do mundo: política, mercado e vida cotidiana em um movimento brasileiro de produção de cultural. 2015.Tese (Doutorado em Antropologia). Universidade Federal do Rio Grande do Sul, Porto Alegre, Rio Grande do Sul, 2015.

KARPINSKI, Lila Fátima; ADOMILLI, Gianpaolo Knoller. Bairro da balsa: conflitos socioambientais e a criação do novo campus da Universidade Federal de Pelotas - RS. IX ANPED SUL - Seminário de Pesquisa em Educação da Região Sul. Universidade de Caxias do Sul, 2009.

LEITE, Ilka Boaventura. Os Quilombos no Brasil: questões conceituais e normativas. Etnográfica, Vol. IV (2), 2000: 333-354.

LONER, Beatriz Ana; ALMEIDA GILL, Lorena. Clubes carnavalescos negros na cidade de Pelotas. Estudos Ibero-Americanos, v. 35, n. 1, 2009.

MAGNANI, José Guilherme Cantor, CAA SILVA, and JK TEIXEIRA. "As festas juninas no calendário de lazer de jovens surdos na cidade de São Paulo." Questões Ambientais e Sociabilidades. São Paulo: Humanitas 1 (2008): 55-76. 
MAGNANI, José Guilherme Cantor. A antropologia urbana e os desafios da metrópole. Tempo social, v. 15, n. 1: 81-95, 2003.

MAGNANI, José Guilherme Cantor; DE LUCCA TORRES, Lilian. Na metrópole: textos de antropologia urbana. São Paulo: Edusp, 1996.

MARTINEZ, Leonil. Xarque com assucar/Pelotas com Nordeste: contraponto de extremos no paladar cultural brasileiro. Dissertação (Mestrado em Literatura). Universidade Federal de Santa Catarina, Santa Catarina, 2000.

MONQUELAT. Adão. A Pelotas dos excluídos. Livraria Mundial, 2012.

NORA, Pierre. Entre memória e história: a problemática dos lugares. Projeto História, São Paulo: CEDUC, n.10, dezembro/1993. p 7-46.

RICOUER, Paul. Temps et récit. Paris: Éditions du Seuil, 1983.

ROCHA, Ana Luiza Carvalho da; ECKERT, Cornelia. Etnografia da duração nas cidades em suas consolidações temporais. Política e trabalho. Revista de Ciências Sociais. João Pessoa, PB. n. 34, 2011. p. 107-126.

ROCHA, Ana Luiza Carvalho da; ECKERT, Cornelia. O tempo e a cidade. Porto Alegre: Editora da UFRGS, 2005.

SALABERRY, Jeferson. A agroindústria no bairro do Porto: Pelotas - RS (1911-1922). Dissertação (Mestrado em Arquitetura e Urbanismo). Universidade Federal de Pelotas. 2012.

SAVAZONI, Rodrigo. A onda rosa-choque: reflexões sobre redes, cultura e política contemporânea. Azougue, 2013.

SAVAZONI, Rodrigo. Os novos bárbaros: a aventura política do Fora do Eixo. Aeroplano Editora, 2014.

SCHLEE, Andrey. Pela Memória de Pelotas. Como sempre! I Colóquio sobre história e historiografia da arquitetura brasileira. Brasília. 2008.

SILVA, Maria Luísa Portocarrero. Conceitos fundamentais de Hemenêutica Filosófica. Coimbra, 2010.

SCHWARCZ, Lilia Moritz. Sobre o autoritarismo brasileiro. Companhia das Letras, 2019.

SIMÕES, Elvis Silveira. No centro e à margem: a trajetória histórica dos trabalhadores arrumadores de Rio Grande-RS, entre as décadas de 1950/60. 2017. Dissertação (Mestrado em História). Universidade Federal de Pelotas, Pelotas, Rio Grande do Sul, 2017.

VELHO, Gilberto. Antropologia urbana: encontro de tradições e novas perspectivas. Sociologia, problemas e práticas, n. 59, 2009. p. 11-18. 
VELHO, Gilberto. Projeto e Metamorfose: antropologia das sociedades complexas. Zahar, 1994.

VELHO, Gilberto. Um antropólogo na cidade, ensaios de antropologia urbana. Rio de Janeiro: ZAHAR, 2013.

VELHO, Gilberto. Individualismo e cultura: notas para uma antropologia da sociedade contemporânea. Zahar, 1987.

XAVIER, J.S. Companhia Hydráulica Pelotense e suas tecnologias: modernidade e progresso - contrapontos da tradição na virada do século XIX. In: SEMINÁRIO INTERNACIONAL DE MEMÓRIA E PATRIMÔNIO, 4, 2010, Pelotas. Anais. Pelotas: Editora da UFPel, 2010. p.573-582.

WHITE, Shane; WHITE; Graham. The Sounds of Slavery: Discovering African American History through songs, sermons and speech. Boston: Beacon Press, 2005.

Data de submissão: 11 de outubro de 2020

Data de publicação: 20 de dezembro de 2021 